\title{
ARTICLES
}

\section{Selective Limitations on Tax Benefits}

\author{
Daniel N. Shaviro $\dagger$
}

\section{INTRODUCTION}

A number of provisions of the Internal Revenue Code deny deductions from gross income that would otherwise be allowable under tax accounting rules, in order to counteract related exclusions or deferrals of income by the taxpayer. For example, $\S 265^{1}$ disallows interest deductions on debt incurred or continued in order to purchase or carry tax-exempt bonds. Similarly, schedular provisions such as the capital loss limitation ${ }^{2}$ and passive loss rules $^{3}$ allow a particular category or "basket" of losses to be deducted only against income from the same basket, largely on the ground that other income from the basket may have been undermeasured by the tax system. These kinds of provisions, which may be called selective limitations on tax benefits ${ }^{4}$, create disparities among taxpayers, denying some income exclusion or deferral they would otherwise receive by specifically disallowing certain deductions.

In this article I will argue that selective limitations cannot intelligibly be analyzed solely through the consideration of first-best

$\dagger$ The author is an Assistant Professor at the University of Chicago Law School. He is grateful to Walter Blum for providing helpful comments and criticism throughout the process of writing the article, to the Scaife Foundation for financial support, and to Charlotte Crane, Richard Craswell, Joseph Isenbergh, Alan Sykes, and Alvin Warren for reading and commenting on earlier drafts.

2 IRC $\$ 265(a)(2)$ (1989), codified at 26 USC $\$ 265(a)(2)$ (1987). All statutory references henceforth are to the Internal Revenue Code of 1986, as amended, codified at Title 26 of the United States Code.

2 Section 1211.

${ }^{3}$ Section 469.

4hese provisions represent only one type of selective limitation. See text at notes 6-12 for a fuller discussion. 
tax principles, particularly the Haig-Simons definition of income. (Haig-Simons holds that income equals the fair market value of the taxpayer's consumption and change in net worth during the relevant accounting period.) $)^{\mathbf{5}}$ Ultimately, selective limitations raise the question what effect the incorrect treatment (from a HaigSimons perspective) of one item should have on any other items; do two wrongs make a right? This question gives rise to secondbest issues that have a discernible theoretical structure with identifiable tradeoffs, but are indeterminate in the absence of empirical information.

I will argue that assessing the merits of a selective limitation requires examining the provision's complex effects on the goals that conformity to the Haig-Simons definition is thought to advance. These goals are twofold: "fairness" or horizontal equity, commonly defined as equal taxation of persons with equal incomes; and "efficiency," which is commonly defined as allocative neutrality with respect to economic resources.

I will show that, under this view, the principal reason (if any) for having selective limitations is that they may reduce the quantity of tax-favored investment and thus improve both fairness and efficiency in certain respects. Yet I will show that selective limitations also have significant fairness and efficiency costs, which may be greater than the gains. For instance, selective limitations may increase the overhead costs of the tax system and encourage avoidance transactions that, in the absence of such limitations, would be irrational. An effective analysis of selective limitations must identify and empirically evaluate the fairness and efficiency tradeoffs of these provisions.

I will also discuss selective limitations under the assumption that one does not want to reduce the quantity of the affected investment (because, for example, one approves of a departure from Haig-Simons taxation). Under this assumption, selective limitations are unambiguously bad: they have fairness and efficiency costs in addition to the undesirable effect of reducing the desired investment.

Section I will define selective limitations and describe the particular provisions on which this article concentrates. Section II will explain why a second-best analysis is necessary, refuting various first-order rationales that have been advanced to support selective

- See Henry C. Simons, Personal Income Taxation 50 (U Chicago, 1938). This definition can be expanded to include consumption that lacks a clear fair market value, such as consumer surplus. See the description of the personal interest exclusion in note 24 . 
limitations. Section III will develop the second-best analysis in depth. Section IV will apply the analysis to the principal selective limitations described in section I.

\section{Definition of Selective Limitations}

\section{A. Background and General Definition}

Selective limitations may be defined in terms of deviations from a Haig-Simons based income tax system. Under a theoretically pure Haig-Simons system, all economic income would be taxed equally. Income, once properly accrued, could neither be excluded nor deferred for tax purposes, and deductions would be allowed only for costs of earning income.

The actual tax system does not-indeed, could not-fully conform to Haig-Simons parameters. Some items theoretically constitute income but cannot readily be measured: consumer surplus, for example, which has an immeasurable psychic value. Other items could be measured only at a significant administrative cost. ${ }^{6}$ For still other items, it is controversial whether they warrant treatment as income (or as deductions) ${ }^{7}$ Finally-and most pertinent to this article-Congress has enacted particular tax preferences designed to under-measure income either through: (1) permanent exclusion from the income base (as is done with income from tax-exempt bonds), or (2) deferral (the treatment given earnings invested in a pension fund and not taxed until the taxpayer retires, and the consequence of allowing accelerated depreciation deductions that outpace actual economic depreciation).$^{8}$

Selective limitations seem to respond to these divergences from the Haig-Simons ideal with countervailing divergences of their own. In general, selective limitations can be defined as provisions that, in response to preferences and resultant income undermeasurement, make certain tax benefits ${ }^{2}$ conditional on the character or amount of other items on the taxpayer's return (or that

- Examples include unrealized appreciation in the value of assets and the imputed rental value of durable consumer assets such as homes and cars. The administrative difficulties posed by taxing such items include not only the need for annual valuations, but also the cash-flow problems regular taxation would cause some taxpayers.

7 See, for example, William D. Andrews, Personal Deductions in an Ideal Income Tax, 86 Harv L Rev 309 (1972), challenging the commonly accepted view that the medical and charitable deductions are preferences.

B Tax credits have a substantive result similar to exclusion, with an element of deferral to the extent of any basis adjustment resulting from the allowability of the credit.

- By "tax benefit" I mean an exclusion, deduction, or credit, without regard to whether the item is a preference. 
would be on the return under an economic definition of income). ${ }^{10}$ Selective limitations therefore cause the Code to treat different taxpayers differently with respect to the same item; under a selective limitation, a particular item may be highly tax-favored (or taxpenalized) in some cases but not others. The net tax benefit depends on the interplay of the items on the taxpayer's return.

There are various provisions other than selective limitations that result in disparate treatment of a single item. For example, graduated marginal rates make the value of a deduction or exclusion vary between taxpayers. Other provisions apply specially to particular types of taxpayers (such as corporations or tax-exempt organizations) without regard to the character or amount of other items on the taxpayer's return. The effects of these provisions may in many respects resemble those of selective limitations.

I have isolated selective limitations for analysis in this article, however, because of two distinctive characteristics they possess. First, since selective limitations are (by definition) provisions that respond to tax preferences, they can be analyzed by concentrating on their effect on preferences. Other disparate treatment provisions necessarily raise additional issues, such as the desirability of rate progressivity or of tax exemptions for charitable organizations. ${ }^{11}$ Second, selective limitations generally present a common range of tax planning problems-problems relating to the mix of activities or investments that a taxpayer chooses and how he chooses to finance them. Nonuniform marginal rates and taxpayerspecific provisions may present different types of problems for taxpayers, although the basic taxpayer goal of minimizing tax liability (all else being equal) remains the same.

To help clarify the analysis, this article focuses on seven particular selective limitations-six Code provisions and one judicial

10 There are provisions that rest the allowability of tax benefits on the character or amount of other tax items yet do not fall within this definition of selective limitations because they do not respond principally to the problem of income under-measurement. Consider, for example, such provisions as the 2 percent floor on miscellaneous itemized deductions ( $\S 67$ ), the 10 percent floor on casualty loss deductions $(\S 165(\mathrm{~h})(2)$ ), the 7.5 percent floor on medical deductions ( $\$ 213(\mathrm{a})$ ), and perhaps the percentage ceilings on charitable deductions $(\S 170(\mathrm{~b})(1)(\mathrm{C}))$. To the extent that such provisions serve purposes unrelated to limiting tax preferences, the analysis in this article is less applicable. See Marvin A. Chirelstein, Federal Income Taxation 147-49 (Foundation, 5th ed 1988) (describing the percentage limitation on medical deductions as serving to identify extraordinary outlays.)

${ }^{11}$ This is not to say that additional issues (such as progressivity) may not affect the merits of selective limitations, although I ignore them in order to simplify the analysis. The point is that tax preference issues are relatively more important to selective limitations than to other disparate treatment provisions. 
doctrine-that share a common feature: they make certain deductions allowable only against a defined category of net taxable income. The seven provisions chosen are the principal existing selective limitations that use this methodology. ${ }^{12}$ However, they use two different means to implement it. Some are expressly schedular: they allow deductions, but only up to the amount of the related taxable income. Others flatly disallow affected deductions on the ground that, since the related income is wholly excluded from tax, the relevant amount of net taxable income is zero. Both types of provisions leave tax benefits undisturbed so long as taxpayers can structure their affairs to avoid encountering the net taxable income limit (which in some cases is zero).

B. The Principal Existing Selective Limitations That Apply a Net Taxable Income Limit on Deductions

1. Nondeductibility of expenses related to tax-exempt income.

Perhaps the most familiar selective limitation is $\S 265$, which denies deductions for expenses allocable to wholly tax-exempt income. ${ }^{13}$ In particular, $\S 265$ denies interest deductions on debt incurred or continued to purchase or carry tax-exempt bonds. ${ }^{14}$ It thereby indirectly denies the benefit of the exclusion to the extent that the taxpayer cannot (or does not) hold tax-exempt assets without incurring allocable debt. ${ }^{15}$

At present, $\S 265$ is fairly narrow in both scope and application. First, it applies only to assets, the income from which is excludable as a matter of law. It does not apply to investments that, while ostensibly taxable, have an effective tax rate of zero or less due to deferral. ${ }^{16}$ Second, in most cases $\S 265$ will reach interest

12 I have previously discussed another selective limitation, the alternative minimum tax, that responds to income mismeasurement by different means. See Daniel N. Shaviro, Perception, Reality and Strategy: The New Alternative Minimum Tax, 66 Taxes 91 (1988). The analysis in the present article generally applies to the minimum tax, $\S 55(\mathrm{~b})$, although that provision raises additional issues such as progressivity. See id at 104-06.

${ }^{13}$ A number of less prominent provisions (including some repealed in 1986) that similarly deny interest deductions because of tax-favored income are listed in Alvin C. Warren, Jr., Accelerated Capital Recovery, Debt, and Tax Arbitrage, 38 Tax Lawyer 549, 549 n 2 (1985).

14 Section 265(a)(2).

1s Since most taxpayers must borrow at interest rates higher than those paid on taxexempt bonds, the amount disallowed under $\S 265$ can exceed the amount of excluded income.

16 Immediate deduction of an investment has the same effect (all else being equal) as excluding all income from the investment. See E. Cary Brown, Business-Income Taxation 
deductions only if the taxpayer is clumsy enough to leave a trail of evidence "tracing" the underlying loan to the tax-exempt asset." As a consequence, some commentators have proposed broadening $\S$ 265 in both respects-treating more kinds of assets as tax-exempt for $\S 265$ purposes, and treating interest deductions as more readily allocable to tax-exempt assets. ${ }^{18}$

2. Nondeductibility of personal interest (other than qualified residence interest).

The Code disallows deductions for personal interest, other than qualified residence interest. ${ }^{19}$ Conceptually, personal interest is interest paid on loans used to finance personal expenditures-on a car, for example, or a vacation. Under the Code, however, personal interest is not identified by tracing loan receipts to such expenditures, but instead is a residual category composed of all interest not otherwise allocated under the Code's myriad interest allocation rules. ${ }^{20}$

Qualified residence interest is interest on loans that are secured by the taxpayer's principal or secondary residence, without reference (in the case of a home equity loan) to the actual use of the borrowed funds. ${ }^{21}$ Often called home mortgage interest, it is conceptually a type of personal interest, but is deductible to the extent that the underlying debt principal does not exceed a maximum of $\$ 1,000,000$ in acquisition indebtedness plus another $\$ 100,000$ in subsequently incurred home equity indebtedness. ${ }^{22}$

As with $\S 265$, the general disallowance of personal interest

and Investment Incentives, in Income, Employment and Public Policy: Essays in Honor of Alvin H. Hansen 300, 309-10 (Norton, 1948); William D. Andrews, Basic Federal Income Taxation 528-30 (Little Brown, 3d ed 1985).

${ }_{17}$ See, for example, William A. Klein, Borrowing to Finance Tax-Favored Investments, 1962 Wis L Rev 608, 609-15. A loan is traceable to a tax-exempt asset for $\S 265$ purposes if its proceeds actually are spent to purchase the asset, or if it is incurred or continued to enable the taxpayer to purchase or carry the asset. See Wisconsin Cheeseman, Inc. $v$ United States, 388 F2d 420 (7th $\mathrm{Cir}$ 1968). More objective and less avoidable rules for interest disallowance apply to financial institutions under § 265(b).

${ }_{18}$ See Calvin H. Johnson, Is an Interest Deduction Inevitable?, 6 Va Tax Rev 123 (1986); George Cooper, The Taming of the Shrewd: Identifying and Controlling Income Tax Avoidance, 85 Colum L Rev 657 (1985).

${ }^{19}$ Section 163(h). Transitional rules allow the deduction of some personal interest for taxable years prior to 1991 . See $\S 163(\mathrm{~d})(6)$.

${ }^{20}$ Section $163(\mathrm{~h})(2)$.

${ }^{21}$ Sections 163(h)(3)(C) and 163(h)(4).

${ }^{22}$ Section 163(h)(3), as revised by the Omnibus Budget Reconciliation Act of $1987 \S$ 10102, Pub L No 100-203, 101 Stat 1330-84 ("Revenue Act of 1987"). Home equity indebtedness is subject to a fair market value ceiling. Section $163(\mathrm{~h})(3)(\mathrm{C})$. 
deductions compensates for an income exclusion: the failure to tax imputed income derived from personal expenditures. ${ }^{23}$ For example, imputed rent from a durable consumer asset such as a car theoretically is income, but is untaxed to the extent that it exceeds the nondeductible depreciation of the asset. ${ }^{24}$ Obviously, the deductibility of qualified residence interest directly conflicts with the rationale of $\S 265$ and is best explained as a consequence of politics or competing policies (such as promoting home ownership).

The indirect disallowance of income exclusions that arise from personal expenditures applies only to taxpayers who cannot (or do not) make such expenditures without incurring allocable debt. The provision does not reduce the tax benefit of financing personal expenditures by, in effect, borrowing from oneself, through the sale or foregone acquisition of an asset that would have produced taxable income. For example, assume that a taxpayer sells a taxable bond that previously had yielded $\$ 1,000$ of interest income per year in order to buy a car that will yield $\$ 1,000$ of imputed rental income per year (net of depreciation). The taxpayer's economic income is unchanged by the purchase, but his taxable income declines by the full $\$ 1,000$ amount that is being excluded. Only if he retains the taxable bond, borrows to buy the car, and thereby incurs at least $\$ 1,000$ of nondeductible personal interest expense, will he fail to gain any net benefit from the $\$ 1,000$ exclusion.

\section{Investment interest limitation.}

Deductions by individuals for investment interest generally are limited to the amount of net investment income. ${ }^{25}$ Thus, if a taxpayer traceably incurs debt in order to hold investment assets (for instance, stocks and bonds not held for sale to customers), the interest deductions from the debt cannot exceed the amount of net taxable income (including capital gains) otherwise derived from

\footnotetext{
23 See Joint Committee on Taxation, General Explanation of the Tax Reform Act of 1986 263-64 (GPO, 1987) ("1986 Bluebook").

24 See Richard A. Epstein, The Consumption and Loss of Personal Property Under the Internal Revenue Code, 23 Stan L Rev 454, 458-62 (1971).

It is less clear that an underlying income exclusion exists when the personal expenditure is not on a durable asset. For example, the benefit from a vacation loan would seem to be consumed in the year of the loan. If so, in subsequent years the taxpayer has no imputed income from the expenditure, but is unable to deduct interest payments. Even then, however, it has been argued that disallowance of subsequent years' interest expense responds to nontaxation of the ongoing psychic benefits (such as pleasant memories or avoided impatience) resulting from the debt-financed expenditure. See Johnson, 6 Va Tax Rev at 160-61 (cited in note 18).

${ }^{25}$ Section 163(d).
} 
the assets. The tracing standard employed here differs, however, from that applied in the $\S 265$ context..$^{28}$

This limitation on excess interest deductions recognizes that investment assets may produce income that is not currently taxed (generally, unrealized appreciation). ${ }^{27}$ Since unrealized appreciation is mostly deferred rather than excluded (in the case of appreciated stock, it would be taxed upon the sale of the stock at a gain), ${ }^{28}$ disallowed deductions are carried forward, rather than permanently denied. ${ }^{29}$ They can be deducted against net investment income in subsequent taxable years. The provision thus indirectly denies the deferral of gain, but only for taxpayers with investment interest expense in excess of current year net investment income.

\section{Capital loss limitation.}

Under § 1211, deductions for losses from the sale or exchange of capital assets generally are limited to the amount of gains from the sale or exchange of such assets. Excess capital loss deductions can be carried over to other taxable years. ${ }^{30}$ This provision responds to the possibility that the taxpayer has unrealized capital gains. ${ }^{31}$ If a taxpayer owns two stocks, one having appreciated by $\$ 1$ million and the other having declined by $\$ 1$ million in value, the provision prevents him from deducting a loss of $\$ 1$ million by selling the loss stock while retaining the appreciated stock. ${ }^{32}$

The capital loss limitation indirectly denies the deferral of gain arising from the realization requirement, but only in one situation-when the taxpayer has realized capital losses that exceed realized capital gains. For example, a taxpayer whose only capital

${ }^{26}$ Tracing in the investment interest context generally looks only at the actual use of loan proceeds, not more broadly at the underlying reason for incurring or continuing indebtedness. Compare Temp Treas Reg $\S 1.163-8 T, 1987-2$ Cum Bull 47, 26 CFR $\S 1.163-8 T$ (allocation under the investment interest limitation) with Rev Proc 72-18, 1972-1 Cum Bull 740-43 (allocation under $\$ 265$ ).

${ }^{27}$ See 1986 Bluebook at $262-63$ (cited in note 23).

${ }^{28}$ Appreciation in the value of an asset can escape taxation permanently under $\S 1014$ (providing for a tax-free step-up in basis at death).

29 Section 163(d)(2).

30 Taxpayers other than corporations are allowed to deduct capital losses in the amount of their capital gains plus $\$ 3,000$ ( $\$ 1,500$ for married taxpayers filing separately). Section 1211(b). See also $\S 1212$ (carryover of disallowed deductions).

${ }^{31}$ See Federal Tax Treatment of Capital Gains and Losses: Hearings Before the House Comm on Ways and Means, 98th Cong, 1st Sess 23 (1983) (statement of John E. Chapoton, Asst Secretary for Tax Policy, Treasury Dept.).

${ }^{32}$ Presumably for administrative reasons, $§ 1211$ applies even when its rationale plainly does not: when the taxpayer has no unrealized capital gains, or indeed no remaining capital assets. 
asset had appreciated by $\$ 1$ million would be wholly unaffected by the provision. The appreciation would not be taxed prior to sale, even indirectly, unless he owned another capital asset that he sold at a loss.

\section{Passive loss rules.}

The passive loss rules generally prevent taxpayers (other than most corporations) ${ }^{33}$ from using deductions and credits from passive activities to offset income or tax liability from non-passive sources. ${ }^{34}$ The Code defines passive activities as all rental activities and those business activities in which the taxpayer does not materially participate. ${ }^{35}$ These activities often are tax shelters. ${ }^{36} \mathrm{~A}$ net loss from one's passive activities is disallowed and carried forward, to be deducted in subsequent taxable years against net income from passive activities. Moreover, a disallowed loss from any particular passive activity is deductible upon a fully taxable disposition of that activity. ${ }^{37}$

The passive loss rules address the concern that investments in passive activities commonly yield net losses for tax purposes that do not reflect true economic losses. ${ }^{38}$ In part, the mismeasurement of income from passive activities may result from deductions implementing tax preferences, such as accelerated depreciation. However, the passive loss rules also disallow deductions that, considered in isolation, would be appropriate under a Haig-Simons approach. The rules do so expressly on the ground that the taxpayer may have other under-measured gain from passive activities. ${ }^{39}$ For example, a taxpayer may have an out-of-pocket loss with respect to a rental building that is offset economically, but not for

ss The rules apply only to individuals, estates, trusts, personal service corporations, and, to a limited extent, closely held "C" corporations. Sections 469(a)(2), 469(e)(2).

s4 Under certain circumstances, passive losses or credits can be used to offset nonpassive income or tax liability. Sections 469 (g), (i). Moreover, disallowed deductions or credits can be carried forward indefinitely. Section 469 (b).

${ }^{33}$ Section 469 (c). A limited partnership interest generally falls short of material participation. Section 469(h)(2); Temp Treas Reg § 1.469-5T(e), 1988-1 Cum Bull 191, 235, 26 CFR $\S 1.469-5 T(e)$. A working interest in oil or gas property generally is not treated as a passive activity regardless of material participation. Section 469 (c)(3).

36 See Daniel N. Shaviro, Passive Loss Rules, 454 Tax Mgmt Portfolios A-1 (1988).

37 When a taxpayer owns interest in more than one passive activity, a complex set of allocation rules dictates what portion of the disallowed loss arose from each activity. See Temp Treas Reg § 1.469-1T(f), 1988-1 Cum Bull 191, 213, 26 CFR § 1.469-1T(f).

${ }^{36}$ See 1986 Bluebook at 209-14 (cited in note 23); Cecily W. Rock and Daniel N. Shaviro, Passive Losses and the Improvement of Net Income Measurement, $7 \mathrm{Va}$ Tax Rev 1, $1-5$ (1987).

so See 1986 Bluebook at 211-13 (cited in note 23). 
purposes of computing taxable income, by unrealized appreciation of the building. Yet the rules have no effect on under-measurement of income unless the taxpayer has a net loss from passive activities.

\section{Nonrefundability.}

A general rule of tax law, followed since the inception of the federal income tax system, provides that net losses for the taxable year are not refundable. A taxpayer with negative taxable income (in other words, deductions in excess of all net taxable income) does not have negative tax liability: the government will not pay him at the applicable marginal tax rate for such negative income. While net operating losses ${ }^{40}$ generally can be carried over to other taxable years, their use in any year depends upon the existence of offsetting positive income. ${ }^{41}$

Nonrefundability is premised in part on a belief that the income tax system properly is concerned only with payments to, not from, the government. Thus, it does not respond merely to concern about excluded or deferred income. However, the merit of this belief about the tax system can be challenged. ${ }^{42}$ One can argue that tax liability is either positive or negative and should vary consistently with income. A company with income of negative $\$ 100$ million arguably is no more similar to one with zero income than is a company with income of positive $\$ 100$ million. Accordingly, perhaps the loss company should pay less tax (that is, a negative amount) than the one with zero income.43

In practice, nonrefundability may derive much of its political appeal from the suspicion that companies reporting tax losses often have economic profits. Thus, to some extent nonrefundability does respond to concern about the exclusion or deferral of income. In effect, it denies deductions that are normative under a HaigSimons approach, as well as preferences, in response to the possi-

${ }^{40}$ For individuals, the net operating loss that can be carried over to other taxable years differs from the amount of negative taxable income, since certain items (e.g., deductions for personal exemptions) cannot be carried over.

41 Even if the taxpayer has net income in a future taxable year, he still loses a portion of the tax benefit of the deductions that gave rise to the net operating loss, since the present value of a carryforward is less than that of a current year deduction.

22 Moreover, the view that income taxation involves only payments to, not from, the government is not an entirely accurate description of current law. Consider, for example, the earned income credit, $\S 32$, which can give rise to a net payment from the government to the taxpayer.

43 See Shaviro, 66 Taxes at 96-97 (cited in note 12); Mark Campisano and Roberta Romano, Recouping Losses: The Case for Full Loss Offsets, 76 Nw U L Rev 709 (1981). 
bility of under-measurement of the taxpayer's economic income as a whole.

\section{Pretax accounting profit requirement.}

Judicial decisions denying tax effect to what are deemed "sham" transactions can be read to require a showing that the transaction had at least a reasonable chance of giving rise to a pretax accounting profit. ${ }^{44}$ This entails a partly subjective analysis, focusing on the taxpayer's profit expectations as well as the objective merit of a transaction. While the scope and legal status of the requirement are far from clear, ${ }^{45}$ some commentators have proposed disallowing deductions associated with all transactions from which the taxpayer did not expect to earn a pretax accounting profit. 6

The doctrine may be based in part on the notion that intentional loss transactions lack a requisite business purpose. However, it also reflects the view that the tax loss reported by a taxpayer in an intentional loss transaction may be largely noneconomic. ${ }^{47}$ As an illustration, consider Knetsch v United States, ${ }^{48}$ in which the taxpayer in effect borrowed at $3^{1 / 2}$ percent in order to invest at $2^{1 / 2}$ percent, thereby incurring economic losses at a rate of 1 percent. For tax purposes, however, he excluded the income side of the transaction, and thus reported losses at a rate of $3^{1 / 2}$ percent. The Supreme Court disallowed all of the losses as the fruits of a sham transaction.

A pretax accounting profit requirement thus denies deductions for what may be real economic costs, on the ground that the net loss reported for tax purposes may be largely noneconomic. Yet, the doctrine does not apply to cases where taxable income from a transaction, while under-measured in relation to economic income,

44 See Knetsch v United States, 364 US 361 (1960); Goodstein v Commissioner, 267 F2d 127 (1st Cir 1959); Ginsburg $v$ Commissioner, 35 Tax Ct Mem Dec (CCH) 860 (1976); Hilton v Commissioner, 74 Tax Ct 305 (1980). (aff'd per curiam 671 F2d 316 (9th Cir 1982)).

${ }^{45}$ See Alvin C. Warren, Jr., The Requirement of Economic Profit in Tax Motivated Transactions, 59 Taxes 985 (1981). More broadly, a profit motive of some kind is necessary to support deductions under $\$ \$ 162$ and 212 . Hobby losses, incurred in activities undertaken without a sufficient profit motive, are nondeductible under $\S 183$.

16 See, for example, Johnson, $6 \mathrm{Va}$ Tax Rev at 130-36 (cited in note 18).

${ }^{47}$ Since an intentional loss transaction is one in which the taxpayer anticipates a pretax economic loss, such a transaction is likely to have such a loss. Yet, the tax benefit of deducting an economic loss does not fully compensate the taxpayer unless the marginal tax rate is 100 percent or greater. Thus, it may be reasonable to expect that the tax loss reported by a taxpayer from such a transaction will be far greater than the actual economic loss.

48 364 US 361 (1960). 
is nonetheless positive. For example, the court in Knetsch presumably would not have considered the transaction a sham if the taxpayer had borrowed (deductibly) at $3^{1 / 2}$ percent to earn (without current inclusion) at 4 percent-although, under those facts, taxable income would have been even more divergent from economic than under the actual facts.

\section{Selective Limitations and Tax Preferences}

Selective limitations are a kind of negative tax preference; they deny tax benefits, but only to the subgroup of taxpayers who cannot (or do not) plan their way around the applicable restrictions. Often the effect of a selective limitation is to deny positive tax preferences, but this is not always the case; to the extent that the taxpayer has real economic losses, for example, nonrefundability goes beyond denying positive preferences.

The selective limitations considered in this article, all of which apply a net taxable income limit on deductions, may reflect intuitions about the inappropriateness of allowing negative tax liability even for portions of the overall tax return. ${ }^{49}$ However, support for selective limitations is closely associated with the goal of limiting the effects of tax preferences, and this goal provides their strongest rationale. ${ }^{50}$ Much of the discussion in this article will thus be based on the assumption that tax preferences are undesirable. ${ }^{51}$

This assumption is not, however, necessary to my analysis. It affects only the evaluation of the effects of selective limitations, not predictions as to what the effects will be. Given that the desirability of tax preferences is disputed and that nonpreferential tax benefits also are affected by selective limitations, I will also consider the issues raised by applying selective limitations to "good" preferences and tax benefits that are not preferences.

I will assume that the policy decision is restricted to whether or not to have selective limitations; the retention of preferences will be treated as a given, although one might prefer repealing them to enacting or retaining selective limitations. As I have discussed elsewhere, the chief impetus for relying on selective limita-

49 Other selective limitations may reflect different intuitions--for example, in the case of the alternative minimum tax, the view that completely eliminating one's tax liability is different in kind and worse than merely reducing it. See Shaviro, 66 Taxes at 93-95 (cited in note 12).

so But see Warren, 38 Tax Lawyer at 556-57 (cited in note 13), suggesting that selective limitations may be used to ensure that tax preferences are claimed in accordance with congressional intent. I will discuss these arguments in section IV.

B1 See text at notes 114-17 for further discussion of this assumption. 
tions is political: for a variety of reasons, Congress may be more willing to respond indirectly than directly to the problems caused by tax preferences. ${ }^{52}$

\section{The Use of First-Best Normative Principles to Deter- mine Whether Selective Limitations are Meritorious}

This section will argue that first-best normative principles are inadequate to assess the merits of selective limitations that restrict undesirable tax preferences. I will first show that the basic HaigSimons definition of income provides no clear indication of the attractiveness of selective limitations. I will then rebut additional lines of normative argument that support selective limitations on the ground that they affect only the unusually "bad" transaction or taxpayer.

An argument for selective limitations that I will not address is the notion that limitations promote the public perception that the income tax system is fair. Professor Stanley Koppelman, for example, supports limitations on interest deductibility on the ground that "the mere appearance of tax avoidance by the wealthy [in the absence of such limitations] would adversely affect tax compliance." ${ }^{33}$ As I have discussed elsewhere, I doubt that selective limitations actually produce significant perception benefits (such as increased taxpayer compliance). And it does seem clear that selective limitations both camouflage remaining problems with the income tax system and debase tax policy analysis into an elusive search for the mere appearance of fairness. ${ }^{54}$

\section{A. Implications of the Haig-Simons Definition of Income}

1. The definition on its face.

As previously stated, under the Haig-Simons definition income is the sum of the taxpayer's consumption and accumulation during

${ }^{82}$ See Shaviro, 66 Taxes at 106-10 (cited in note 12).

${ }^{53}$ Stanley A. Koppelman, Tax Arbitrage and the Interest Deduction, $61 \mathrm{~S} \mathrm{Cal} \mathrm{L} \mathrm{Rev}$ 1146, 1203 (1988). See also 1986 Bluebook at 210 (cited in note 23) ("Extensive shelter activity contributed to public concerns that the tax system was unfair, and to the belief that tax is paid only by the naive and unsophisticated. This, in turn ... undermined compliance. . . .").

54 See Shaviro, 66 Taxes at 97-102 (cited in note 12). For an example of the difficulties of relying on presumed public perceptions, see Koppelman, $61 \mathrm{~S}$ Cal L Rev at 1214 (cited in note 53). Professor Koppelman supports limitations on interest deductibility largely to foster the perception that the income tax system is fair, and yet admits that his preferred allocation method (stacking) would itself create perceptions of unfairness. His analysis seems to return him to the problem with which he began. See id at 1216. 
the relevant accounting period. Both "consumption" and "accumulation" are defined in objective fair market value terms, largely due to the difficulty of subjective valuations. The definition generally disregards items that are thought to lack a measurable fair market value, such as the psychic value of leisure. ${ }^{55}$

The Haig-Simons definition powerfully illuminates a number of issues about the nature of income. For example, it defines income without distinctions as to source. It suggests disregarding financial accounting conventions such as the realization requirement. ${ }^{56}$ It requires netting, or the subtraction from gross income of expenses other than those incurred for consumption. ${ }^{67}$ If the HaigSimons definition were considered a normative standard, it would require the repeal of tax preferences.

All of these issues, however, involve the same basic question: what are the contours of the term "income"? Selective limitations pose a very different question: what consequences should we attach to a failure to follow those contours? In some cases (such as $\$ 265$ ), selective limitations deny deductions that Haig-Simons would allow, as a response to exclusions or deferrals that Haig-Simons would bar. In other cases (such as the passive loss rules), they allow or deny deductions without regard to Haig-Simons principles, based only on the amount of offsetting taxable income. ${ }^{58}$ Whereas Haig-Simons only states an ideal, selective limitations respond to the non-fulfillment of an ideal. The Haig-Simons definition provides neither theoretical nor practical guidance regarding the proper consequences of a departure from its terms.

Can the Haig-Simons definition nonetheless yield indirect guidance regarding selective limitations? Commentators have tried two different approaches, one opposing the limitations and one supporting them. Both views are based on proximity claims- assertions that the limitations move the tax system toward or away from the Haig-Simons ideal.

ss See Simons, Personal Income Taxation at 50-56 (cited in note 5). But see notes 5 and 24 for situations where Haig-Simons can be expanded to include forms of psychic income.

se Id at 80-89.

${ }^{37}$ Consumption expenses are disallowed, even though they diminish wealth, because the value of what they purchase is assumed to equal their cost.

ss Some selective limitations, such as the alternative minimum tax, may unambiguously move income closer to conformity with the Haig-Simons definition. However, given the nonuniversal effect of such rules, their desirability under Haig-Simons assumptions remains unclear. See text at notes 73-76. 
2. Selective limitations as moving us further from HaigSimons conformity.

Those who believe that selective limitations move us further from Haig-Simons conformity generally do not contend that tax preferences are desirable. On the contrary, opponents of selective limitations often view tax preferences not only as inconsistent with Haig-Simons, but as unjustifiable on nontax social policy grounds. ${ }^{59}$ Such opponents argue, however, that two wrongs do not make a right. The prior error of mismeasuring income through the enactment of a preference does not justify a second and separate error of denying deductions for true economic costs. ${ }^{60}$ For example, assume that economic income from tax-exempt bonds should be included in income and, further, that the economic costs of holding such bonds (for instance, interest paid on loans) should be deducted from income. Failing to do the former does not necessarily mean one should fail to do the latter. Selective limitations seemingly compound the harm done by preferences, by increasing the number of mistakes made by the tax system in measuring taxable income.

The weak link in this argument is the assumption that divergence from Haig-Simons is a function of the number of separate mistakes made, not of the mistakes' net effect. The argument ignores the obvious proposition that a greater number of mistakes may be better than a lesser number if the mistakes are offsetting. As a simple example, assume that Congress passed a law allowing everyone whose last name began with $T$ to deduct $\$ 5,000$ of noneconomic costs. A second law requiring everyone whose last name began with $\mathrm{T}$ to over-measure gross income by $\$ 5,000$ obviously would improve the accuracy of income measurement. Advocates of the "fewer errors" position could try to distinguish this case semantically, as involving a thinly veiled repeal of the first mistake rather than a new and separate error. Much of the analysis that underlies the "fewer errors" position attempts to show that

\footnotetext{
s9 See Melvin I. White, Proper Income Tax Treatment of Deductions For Personal Expense in Andrews, Basic Federal Income Taxation at 475 (cited in note 16); Philip D. Oliver, Section 265(2): A Counterproductive Solution to a Nonexistent Problem, 40 Tax L Rev 351, 354 n 10 (1985).

so Schedular selective limitations generally disallow deductions for true economic costs as well as for tax preferences. For example, the passive loss rules apply to out-of-pocket costs as well as to preferential depreciation, and the capital loss limitation denies deductions for losses that, considered in isolation, unquestionably are economic. The argument that selective limitations move us further from Haig-Simons conformity plainly is more difficult to make when the disallowed deduction is a tax preference.
} 
selective limitations are not as closely linked to income exclusions or deferrals as the over-measurement in the above example. ${ }^{61}$

Yet advocates of "fewer errors" fail to recognize the breadth of the point that the above example makes, particularly as one gradually weakens the "fit" between the two errors. For instance, one could change the example so that the corrective legislation affected only some of the taxpayers whose names began with $\mathrm{T}$, affected even those taxpayers in varying degrees, and also inadvertently applied to some taxpayers whose names began with $B$ or $D$. There is no bright line indicating at what point the corrective legislation would cease to be an improvement.

The example concerning taxpayers whose names begin with $\mathrm{T}$ is related to the theory of the second best. ${ }^{62}$ This theory holds that if one or more constraints prevents the attainment of optimal conditions, one cannot predict in the abstract whether removing any other constraints will improve or worsen conditions. ${ }^{63}$ As an example of a second-best problem, assume that an optimal social allocation of resources results when all products are priced at marginal cost, but that in one sector of the economy prices are considerably above marginal cost (and output accordingly restricted) due to a natural monopoly. Under these circumstances, the optimality of resource allocation is not necessarily enhanced by eliminating monopolies in all other sectors of the economy. ${ }^{64}$

The theory of the second best derives its force from the fact that optimality often results from a balance. There is no secondbest answer, for example, to the question of how much cyanide one should consume to improve one's health: the answer is always as little as possible. In the monopoly example, however, a notion of balance is implicit. If a monopolized industry, left to itself, would

B1 See White, Proper Income Tax Treatment at 475-76 (cited in note 59); Oliver, 40 Tax L Rev at 397-402 (cited in note 59); George Mundstock, Accelerated Depreciation and the Interest Deduction: Can Two Rights Really Make a Wrong?, 29 Tax Notes 1253 (1985).

${ }^{62}$ In technical economic parlance, the example concerning the taxpayers whose names begin with $\mathrm{T}$ might be described as involving externalities, rather than the theory of the second-best. The corrective legislation directly (even if imperfectly) offsets the distortion from prior law, whereas a second-best response might have involved, for example, providing comparably distortive benefits to taxpayers whose names did not begin with $\mathrm{T}$. However, both externalities and the theory of the second-best involve the same broader principle: that a particular distortion may have a net anti-distortive effect in light of other distortions. The overlap is reflected in common usage of the term "second-best," and I will follow common-rather than technical economic-usage.

${ }^{63}$ See R.G. Lipsey and Kelvin Lancaster, The General Theory of Second Best, 24 Rev Econ Stud 11 (1956).

ot See, for example, Frederic M. Scherer, Industrial Market Structure and Economic Performance 24-25 (Rand McNally, 2d ed 1980). 
produce too little of a particular good, then resource allocation may improve if any new distortion increases production by the industry. Destruction of all monopolies remains the first-best answer (at least, if one assumes away all other distortions), but other, compensating distortions may be second-best.

The underlying notion of balance supports responding to distortions even if the response is not sufficiently well-calibrated to restore a first-best state. Since any departure from optimality may distort all underlying balances, all other normative assumptions are impeached. ${ }^{65}$ A comprehensive system such as an economy (or a tax system) has too many complicated interactions among different areas to permit the a priori assumption that any particular distortion can simply be contained or ignored. ${ }^{66}$

The theory of the second best questions the achievement of optimality through piecemeal reform, calling into doubt any approach other than the global removal of distortions. ${ }^{67}$ Its prescriptive implications are far less clear. At a minimum, it entails a highly fact-specific analysis. ${ }^{68}$ Moreover, especially given limited or imperfectly quantifiable data, it suggests that often there is no single second-best solution, but rather a range of possible approaches. ${ }^{69}$

In any case, the considerations of balance that underlie the theory of the second-best clearly refute the argument that selective limitations are bad solely because they increase the total number of tax provisions that mismeasure income. In evaluating selective limitations, one cannot shrug off as beyond the scope of inquiry the under-measurements of income to which they expressly respond. ${ }^{70}$

3. Selective limitations as moving us toward Haig-Simons conformity.

A number of commentators maintain that selective limitations

65 See Lipsey and Lancaster, 24 Rev Econ Stud at 11-12 (cited in note 63).

${ }^{68}$ See Scherer, Industrial Market Structure at 24 (cited in note 64).

${ }^{87}$ See Charles K. Rowley and Alan T. Peacock, Welfare Economics: A Liberal Restatement 21 (Halsted, 1975); Scherer, Industrial Market Structure at 24-25.

${ }^{68}$ Scherer, Industrial Market Structure at 24; for an example of such detailed analysis see Richard S. Markovits, A Basic Structure for Microeconomic Policy Analysis in Our Worse-Than-Second-Best World: A Proposal and Related Critique of the Chicago Approach to the Study of Law and Economics, 1975 Wis L Rev 950, 968-69.

Bo See Scherer, Industrial Market Structure at 25.

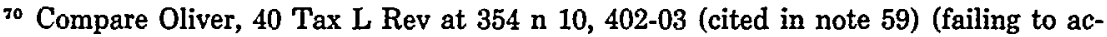
knowledge this point). 
move the tax system closer to Haig-Simons conformity. For example, Professor Calvin Johnson argues in favor of selective limitations that apply transactional "matching." Matching identifies the gross income and expenses that arise in the same transaction and disallows the latter if the former is excluded or deferred. ${ }^{71}$ Johnson supports transactional selective limitations on the ground that they increase the accuracy of income measurement. ${ }^{72}$ As an example of his point, assume that Taxpayer X borrows in order to buy tax-exempt bonds, and realizes $\$ 10$ both of gross income and of interest expense. X's net economic income, of course, is zero. However, given the legally mandated exclusion of the receipts, we will mismeasure $X$ 's net income unless we also disallow the interest deduction. ${ }^{73}$

Johnson recognizes that his point involves second-best considerations; ${ }^{74}$ he advocates a secondary distortion to offset the prior income exclusion. However, he does not pursue the second-best analysis at any length, and instead generally argues from normative first principles. ${ }^{75}$ Yet the skepticism of second best theory, and its requirement of fact-specificity, counsel against so quickly concluding that any particular proposal is in fact second-best. In dealing with transactional selective limitations, one must consider the consequences of a transactional rule's failure to create uniform connections between exclusions or deferrals on the one hand, and disallowed deductions on the other.

If all taxpayers were in X's position from the above example, it would be easier to accept transactional selective limitations. Haig-Simons conformity would be restored by the deduction disallowance, at least with respect to the measurement of income from tax-exempt bonds. The overall accuracy of income measurement

71 Johnson, $6 \mathrm{Va}$ Tax Rev at 123 (cited in note 18).

${ }^{72}$ Id at $128,157$.

73 The same point can be made about schedular selective limitations, so long as they in fact reach excluded or deferred income. Assume that a taxpayer has $\$ 10$ of unrealized gain from a passive activity (for example, the appreciation of a rental building) and a $\$ 10$ cash loss from a second passive activity. Disallowance of the $\$ 10$ passive loss deduction increases the accuracy with which we measure income from the taxpayer's passive activities.

34 Johnson, $6 \mathrm{Va}$ Tax Rev at 158 (cited in note 18).

73 Johnson's second-best analysis is largely confined to repeating an illustration from Markovits, 1975 Wis L Rev at 968-69 (cited in note 68), in which a car is optimally turned by rotating the wheel 90 degrees for the first second if the car is moving at 10 miles per hour, but only 20 degrees per second if moving 56 miles per hour. Professor Johnson draws from this example the conclusion that, "If you are driving at 56 m.p.h., do not turn so sharply," Johnson, $6 \mathrm{Va}$ Tax Rev at 158 (emphasis in original), but does not go beyond this rhetorical flourish to examine the second-best issues. He makes one later reference to the second-best problems but again fails to explore its implications. Id at 181. 
would increase even if the amount excluded and the amount disallowed differed somewhat (if each taxpayer who was holding taxexempt bonds had $\$ 5$ of deductions disallowed for every $\$ 10$ of tax-exempt income).

But because the effect of a selective limitation varies with the taxpayer, we are faced with a far more difficult issue. Taxpayer $\mathrm{X}$ may have $\$ 10$ of interest expenses that are traceable to holding tax-exempt bonds, $\mathrm{Y}$ may have no such expenses, and $\mathrm{Z}$ may have $\$ 5$ (or $\$ 15$ ). Thus, disallowing interest deductions would deny the benefit of the preference in full to $\mathrm{X}$, not at all to $\mathrm{Y}$, and 50 percent (or 150 percent) to $\mathrm{Z}$.

This type of disparity greatly complicates the question whether selective limitations advance normative goals. For example, assume that we favor Haig-Simons in order to maximize horizontal equity (the equal taxation of persons with equal incomes). Should we care more that a selective limitation discriminates against a sub-class of the taxpayers who otherwise would benefit from preferences, or that it causes that sub-class to be treated more like the taxpayers who did not benefit from preferences to begin with?

Or assume that we favor Haig-Simons for reasons of allocative efficiency; that is, we do not want the tax system to alter market allocations of resources. If taxpayers are treated disparately by a selective limitation, they presumably will respond; to use the example above, taxpayers like $\mathrm{X}$ and $\mathrm{Z}$ will reallocate tax-exempt bonds to taxpayers like $Y$. If unaffected taxpayers can absorb enough preferences, there may be little change in the amount of tax-exempt bonds in the economy, and thus in allocative efficiency. But such taxpayer responses themselves have economic costs. ${ }^{76}$ Thus, before assuming that a selective limitation enhances efficiency, one wants to know something about the magnitude and effect of taxpayer responses.

In any case, the question of whether selective limitations bring the tax system closer to Haig-Simons conformity cannot be answered from the terms of the income definition itself. Selective limitations conceivably could make the tax system less fair and less efficient, depending on their actual effects in relation to tax preferences.

76 For example, selective limitations may increase asset churning, tax planning, the cost of administering the tax system, and (in many cases other than tax-exempt bonds) the proportion of productive assets held by relatively inefficient producers. See text at note 167 . 
B. First-Best Theoretical Grounds Other than the Haig-Simons Definition for Selective Limitations

The second-best nature of selective limitations suggests that one must compare their benefits and costs. Since the limitations make the tax system more fair and efficient in some respects but less so in others, one needs to determine which effect is greater or more important. A second-best analysis arguably would support selective limitations even if they made arbitrary distinctions. The arbitrariness merely gives rise to certain fairness and efficiency costs that need to be weighed against the benefits.

The second-best analysis is presented in section III. Before turning to it, however, I will consider various arguments that have been made suggesting that particular selective limitations are not arbitrary; that instead they correctly identify unusually "bad" transactions or taxpayers. These arguments, if correct, would suggest that a detailed weighing of the benefits and costs of selective limitations is not necessary, because a provision is highly likely to be beneficial on balance if it applies to bad cases while leaving good ones alone.

The arguments in support of selective limitations fit into three categories. First, there are transactional arguments for rules that attempt to associate deductions with items of excluded or deferred income from the same transaction. Second, there are anti-spreading arguments for rules that limit the types of income against which particular deductions can be used, so as to prevent "sheltering" of positive income sources such as salary. Third, there are anti-leverage arguments for rules that limit interest deductions because of untaxed income. The remainder of this section will show that each of these arguments is unpersuasive. Selective limitations make arbitrary distinctions and thus must be assessed on general second-best grounds.

\section{Transactional arguments for selective limitations.}

Various commentators support selective limitations that disallow a deduction if the gross income from the same transaction is not taxed. ${ }^{77}$ For example, Professor Johnson notes that costs incurred by a corporation to issue stock are not deductible, even though such costs reduce the corporation's wealth, since the proceeds of the sale are tax-exempt. ${ }^{78} \mathrm{He}$ argues for extending the ap-

77 See Johnson, $6 \mathrm{Va}$ Tax Rev at 126-29, 157 (cited in note 18).

78 Johnson, 6 Va Tax Rev at 128, 157. See § 1032. 
proach to all transactions, on the ground that it permits the income from a transaction to be measured more accurately, ${ }^{79}$ as in the tax-exempt bond example discussed above. ${ }^{80}$

The question arises, however, why transactions are a uniquely appropriate level at which to measure income accurately, given that the existence of preferences suggests continued mismeasurement at the overall taxpayer level. To justify this, Professor Johnson relies principally upon a perceived duty of taxpayers to be consistent. He argues that the connection between different items arising in the same transaction requires that they be treated consistently (either both be taken into account or both be ignored for tax purposes). In his view, a taxpayer who deducts an outlay while excluding the related inflow has "mismatched" the two items, and thus is little better than one who seeks to deduct the same cost twice. ${ }^{81}$

Whether the items are linked objectively ("something comes in for the outlay") 82 or subjectively ("something explains why the outlay was made") ${ }^{83}$ the point is one of but-for causation: but for the expense, there would have been no income, and but for the attempt to acquire income there would have been no expense. Yet, it is hard to see why but-for causation should matter. Certainly, the duty of consistency is not as clear in the case of a transaction as in the double deduction context. If a taxpayer can deduct the same cost twice, or deduct a cost in one year while excluding its recovery in another year, ${ }^{84}$ then his income is mismeasured over time without apparent justification. But the only mismeasurement in the case of a transactional "mismatch" is the exclusion of the gain which, good policy or not, would have followed anyway in the absence of a traceable expense.

An insistence on transactional consistency ignores the similarity between actual transactions and invisible or implicit ones. For example, the cash cost of paying interest on debt borrowed to finance a tax-favored investment is similar economically to the opportunity cost of "borrowing" from oneself by foregoing taxable returns from alternative investments. ${ }^{85}$ Yet the transactional view

78 Id at $126,128,157$.

${ }^{80}$ See text at notes 73-76.

81 Johnson, 6 Va Tax Rev at 146-47.

${ }^{82}$ Id at 157 .

83 Id.

84 See Commissioner v Tufts, 461 US 300 (1983) (identified by Johnson, 6 Va Tax Rev at 147, as involving a duty of consistency similar to that in the transactional context).

${ }^{85}$ See Klein, 1962 Wis L Rev at 609-10 (cited in note 17) (taxpayers can achieve the 
does not reach these imputed self-charged interest expenses. The "mismatch" argument might at least have aesthetic appeal if actual items could reliably be linked by but-for causation. In practice, however, this is not the case. Transactional associations between items not only are difficult to prove, but may at times be fictitious to begin with. Assume that Taxpayer $\mathrm{X}$ owns an asset that he could sell for $\$ 10,000$, but decides to borrow $\$ 10,000$ for a vacation. Or assume that he receives the asset after the vacation, but elects not to repay the outstanding loan balance immediately. The but-for causation of the ongoing annual interest expense is unclear. True, $\mathrm{X}$ would not be incurring it if he had not gone on vacation, but he also would not be incurring it if he were willing to sell the asset. Perhaps the most intellectually consistent way to determine but-for causation in this context is through the hypothetical examination of what $\mathrm{X}$ would have done if forced to choose. Would he sooner have sold the asset or foregone the vacation? Even $\mathrm{X}$ may not know the answer to this question.

While this hypothetical highlights the significant administrative problems of matching, it is vastly simpler than many real-life examples regarding the causation of interest expense. Taxpayers commonly have a range of assets and engage in a range of activities that may require borrowing. They often will not bother to figure out why they "really" incur or continue a debt; they do not know which assets or expenditures they rank lowest in priority and would have foregone but for the borrowing. ${ }^{86}$ Moreover, even assuming conscious taxpayer intent, efforts by the courts and the Internal Revenue Service to infer such intent from objective factual circumstances have been notoriously limited in range and success. ${ }^{87}$

The near impossibility of finding but-for causation, which results from the fungibility of money, plagues interest expense. Yet, interest expense is the principal subject of transactional selective limitations under both current law and most proposals to expand the limitations.

Due to the difficulty of finding but-for causation for interest expense, advocates of transactional selective limitations are willing

\footnotetext{
same results by selling taxable investments in order to buy tax-free investments, as by borrowing to make the purchases).

${ }^{88}$ See C. Eugene Steuerle, Tax Arbitrage, Inflation, and the Taxation of Interest Payments and Receipts, 30 Wayne L Rev 991, 1006 (1984).

${ }^{87}$ See, for example, Wisconsin Cheeseman, 388 F2d 420; and Rev Proc 72-18, 1972-1 Cum Bull 740 (interpreting the purposive standard of $\$ 265$ ).
} 
to accept arbitrary objective approaches, such as proration of interest deductions between tax-exempt and taxable income, or a "taint first" rule. ${ }^{88}$ Such an approach has obvious administrative advantages. Once it is accepted, however, what remains of the transactional view? Items are associated with each other purely on prescriptive grounds, without any reliance on actual causal links between them. When such an approach is termed "transactional," the real mismatch is not between two items from the same transaction; it is between rhetoric and policy proposals.

\section{Anti-spreading arguments for selective limitations.}

A second ground for viewing particular selective limitations as distinguishing coherently between "better" and "worse" taxpayers or investments focuses on the use of noneconomic losses from one source to avoid tax on income from others. ${ }^{89}$ For example, a taxpayer may engage in intentional loss transactions or incur passive losses to offset his salary income. The anti-spreading viewpoint suggests that such activities are worse than simply avoiding tax on income from a single source..$^{90}$

a. Are "loss" investments different and worse than other investments? Commentators oppose spreading partly on the ground that investments producing foreseeable pretax losses are generally unmeritorious. Professor Johnson, for example, supports an expansive pretax accounting profit requirement by arguing that, since such profit is an indicator of social utility, intentional loss transactions are "nonsense" and "silliness," involving "utterly worthless property."

The problem with this argument, as Professor Alvin Warren has shown, is that similar criticisms can be made of almost any

ss Johnson, 6 Va Tax Rev at 173-74 (cited in note 18). Thus, Johnson proposes "match[ing] the interest to tax-exempt investments without regard to the order of borrowing and investment, the actual trail of the loan, or the taxpayer's motives." Id at 173.

89 See Johnson, 6 Va Tax Rev at 129-36; and Cooper, 85 Colum L Rev at 672-76 (cited in note 18).

${ }^{20}$ Commentators seek to prevent spreading in part for practical reasons. See Johnson, 6 Va Tax Rev at 129-30 (if spreading is allowed, once income from any source is exempted, "we [cannot] maintain a tax on income from any [other] source"). To this extent, the argument simply could be one of volume: if we want to restrict the amount of tax-exempt investment (or to protect tax revenues), anti-spreading rules may be useful. As discussed below, however, text at note 97, Johnson and Cooper view anti-spreading rules as logical, not just practical; they believe the rules address mismeasurement that somehow is worse than usual and not merely convenient to single out.

9 See Johnson, 6 Va Tax Rev at 123, 134-35, 143. 
tax-favored investment. ${ }^{22}$ For example, tax-exempt bonds generally offer a lower pretax return than taxable but otherwise comparable financial instruments. Taxpayers purchase tax-exempt bonds because the after-tax return is made competitive by the exemption. Thus investments in tax-exempt bonds, like investments in intentional loss transactions, are "nonsense" on a pretax basis. ${ }^{93}$

Accordingly, Professor Warren argues that if we require a pretax accounting profit, there is no principled ground for affording favorable tax treatment to any investment in which the expected pretax profit is below the maximum available (in other words, in which the taxpayer may have invested solely by reason of preferences that increase the after-tax return). Rather, we should require investments to show as great a pretax profit as that available in the wholly taxable context. ${ }^{94}$

Applying anti-spreading rules to losses but not to reduced gains does not even enable one to penalize the "worst" investments. This is particularly true of schedular selective limitations, such as the capital loss limitation and the passive loss rules, that can be avoided by simply keeping enough positive income in the basket that contains the potentially limited deductions. But a pretax accounting profit requirement likewise fails to identify the "worst" transactions, at least if one treats interest expense incurred (but not foregone returns from alternate investments) as a cost.

Assume, for example, that $\mathrm{X}$ and $\mathrm{Y}$ are both investors concerned solely with maximizing after-tax profitability, but have different investment opportunities. Due to tax considerations, $\mathrm{X}$ borrows at 10 percent to make an investment with a pretax return of 8 percent. $Y$, also for tax reasons, foregoes a pretax return of 10 percent and invests his own cash at a pretax return of 6 percent. If pretax yields determine merit, then $X$ 's investment is "better." Yet only Y's investment has a pretax accounting profit.

b. Is creating negative tax liability different from reducing positive tax liability? Despite Professor Warren's point that there is no principled difference between investing at a reduced pretax profit for tax reasons and investing at a pretax loss for tax reasons, one could argue for an anti-spreading rule on pragmatic grounds. One could point out that even if drawing a line in a particular

${ }_{82}$ Warren, 59 Taxes at 989 (cited in note 45).

${ }^{83}$ Moreover, a tax-exempt issuer's use of the bond proceeds may have less social utility than alternative uses, since the issuer can ignore a portion of the true cost of its borrowing.

94 Warren, 59 Taxes at 989, 991-92 (cited in note 45). 
place is arbitrary, it does not follow that no line should be drawn at all. To the extent that preferences distort investment decisions, any specific requirement short of maximum pretax profitability, even though arbitrary, would arguably improve the average quality of investments. Thus, even if penalizing an expected pretax loss is no more logical than requiring an expected pretax profit of, say, 1.20695483 percent, it might be better than no rule at all.

Advocates of anti-spreading rules, however, view zero as a uniquely appropriate place for line-drawing, and not just for reasons of simplicity. They base this view on a distaste for "negative taxes." Tax-exempt bonds, for example, are taxed at zero by reason of the exemption. Yet, if investing in the bonds (coupled with borrowing) gives rise to losses that are deductible against other income, then the bonds are better than exempt. They provide a net gain from the tax system by reducing taxes with respect to other income. ${ }^{\text {95 }}$

However, the commentators fail to explain why a negative tax should be distinguished from any other tax benefit. Professor Warren's point about transactional rates of return applies here with equal force. A negative tax rate on an investment is no different in theory from a reduced, but still positive, tax rate. Commentators object to the former because it provides a subsidy and distorts resource allocations; ${ }^{96}$ yet these objections apply to the latter as well.

Non-second-best arguments for anti-spreading rules rest on

98 See Johnson, $6 \mathrm{Va}$ Tax Rev at 125-26 (cited in note 18), arguing that only a negative tax goes beyond tax relief to provide an actual government subsidy. Yet it has long been understood, under "tax expenditure" doctrine, that a reduction in tax liability may be the same in principle as a direct expenditure of government funds. See Stanley S. Surrey, Pathways to Tax Reform: The Concept of Tax Expenditures 126-54 (Harvard, 1973). See also Cooper, 85 Colum L Rev at 674 (cited in note 18), criticizing negative taxes for indirectly reducing the tax burden on unrelated income such as salary. He views this as a profound "tax alchemy" that effectively transmutes such unrelated income from taxable to tax-exempt form. Id. Yet this point would vanish if net losses incurred by a taxpayer were refundable. In that case, there would be no reason to view the allowance of losses from tax-favored transactions as transmuting other income. Instead, all losses would be compensable from the Treasury, and gain transactions clearly would remain taxable (e.g., in the net loss situation, they would reduce the payment due from the Treasury). The characterization of spreading as permitting "tax alchemy" assumes nonrefundability without showing why it is the proper rule.

Anti-spreading rules may be even less internally logical than nonrefundability. They beg the question as to why one item of income is more properly offset than another by a particular deduction. Moreover, they require one to determine which items arise from a particular source. We already have seen how serious this problem can be under transactional rules. It is a problem under schedular rules as well, as most practitioners would readily attest if asked to identify their clients' capital assets or passive activities.

96 See Johnson, $6 \mathrm{Va}$ Tax Rev at 140 (cited in note 18). 
the economically dubious assumption that a minus or loss is not the equivalent in reverse of a plus or gain. Such arguments assume their conclusion that the term "tax liability," by definition, ought not to be negative as well as positive. Yet such assumptions violate the basic notion of equity that only likes should be treated alike. For example, a person with investment income of negative $\$ 100$ million probably should not pay the same current year income tax, in absolute terms, as one with zero investment income.

For these reasons, the anti-negative tax rationale for antispreading rules is not abstractly correct. Anti-spreading rules, like any other departure from Haig-Simons conformity, can be defended only to the extent that they succeed in practice in offsetting prior departures. For example, there is little reason to favor them if-because taxpayers can easily avoid them-they do not in fact significantly reduce the quantity of tax-favored investment.

3. Anti-leverage arguments for selective limitations.

A number of commentators, including Professor William Andrews and Eugene Steuerle, have identified leverage, or the practice of investing borrowed funds, as a critical element in tax shelter investments. ${ }^{97}$ From this observation, other commentators have concluded that, short of repealing preferences, disallowing interest deductions is the most appropriate way to attack income mismeasurement. ${ }^{98}$ The argument is based on the claim that leverage dramatically enhances after-tax rates of return from tax-favored investments. This enhanced rate of return is thought to show that leverage, at least in combination with preferences, is per se abusive or problematic.

The analysis of the effect of leverage on rates of return has been developed most elegantly by Professor Andrews, although he does not draw any conclusions about selective limitations. ${ }^{99}$ Profes-

${ }^{97}$ Andrews, Basic Federal Income Taxation at 618-20 (cited in note 16); Steuerle, 30 Wayne L Rev at 1002-06 (cited in note 86).

${ }^{98}$ See Cooper, 85 Colum L Rev at 672-76 (cited in note 18); Johnson, 6 Va Tax Rev at 126 (cited in note 18). In large part, theoretical hostility to leverage is merely an extension of transactional and anti-spreading arguments for selective limitations. Commentators deplore the transactional mismatch between deductible interest costs and untaxed economic returns. See, for example, Calvin H. Johnson, Tax Shelter Gain: The Mismatch of Debt and Supply Side Depreciation, 61 Tex L Rev 1013, 1019 (1983); Cooper, 85 Colum L Rev at 672. Further, the commentators note that interest deductions can be used to "spread" the tax benefit of an exemption and shelter income from unrelated sources. Johnson, $6 \mathrm{Va}$ Tax Rev at 129-30; Cooper, 85 Colum L Rev at 674.

${ }^{98}$ See Andrews, Basic Federal Income Taxation at 618-20 (cited in note 16). 
sor Andrews posits the case of a taxpayer in the 40 percent bracket who pays $\$ 1,000$ for a perpetual bond that provides taxable interest at 12 percent. The taxpayer is permitted, as a preference, to deduct the cost of the bond. If she pays cash for the bond, she is $\$ 600$ out of pocket after benefiting from the preferential deduction, and receives an annual return of 12 percent on this out-of-pocket cost (based on the $\$ 72$ of interest she retains after paying tax at 40 percent).

Professor Andrews asks us to assume alternatively, however, that the taxpayer pays only $\$ 500$ out-of-pocket for the bond and borrows the other $\$ 500$ at 12 percent, ${ }^{100}$ with interest payments deductible. Now the taxpayer is out-of-pocket only $\$ 100$ after tax, and yet nets $\$ 36$ ( $\$ 72$ of interest received, minus $\$ 36$ of interest expense, after accounting for the tax consequences of each). Her rate of return in relation to her out-of-pocket cost (disregarding the borrowed funds) has tripled, to 36 percent.

Moreover, in the second hypothetical the taxpayer's rate of return on her out-of-pocket cost was 12 percent before tax, ${ }^{101}$ and tripled only when taxes were taken into account. In the first hypothetical, by contrast, the rate of return was 12 percent both before and after tax, despite the preference. Professor Andrews therefore characterizes the effective rate of tax in the second hypothetical (by which he means the tax system's effect on the rate of return) as negative 200 percent. ${ }^{102}$

Professor Andrews does not argue that leveraged transactions are worse than others or that such transactions are appropriately singled out by selective limitations. ${ }^{103}$ Instead, his point seems to be that leverage dramatically illustrates the broader effects of preferences. Since others have drawn the larger conclusions about leveraged transactions, however, ${ }^{104}$ it is worth examining more closely the methodology employed by rate-of-return analysis.

Professor Andrews explains that leverage alters the after-tax rate of return because it "increases the relative impact" of tax

${ }^{100}$ Professor Andrews's example posits that she borrows at 11 percent, but for simplicity I am adopting a single interest rate.

${ }^{101}$ Before tax, the taxpayer is out-of-pocket $\$ 500$ and receives a net return of $\$ 60$ ( $\$ 120$ interest received minus $\$ 60$ interest paid).

${ }^{102}$ Andrews, Basic Federal Income Taxation at 618 (cited in note 16).

${ }^{103}$ Professor Andrews does, however, appear to view the combined effects of leverage and preferences with sufficient concern to comment: "A negative income tax indeed!" Id at $618,1362$.

${ }^{104}$ See Johnson, $6 \mathrm{Va}$ Tax Rev at 130-32 (cited in note 18). 
preferences, ${ }^{105}$ that is, their impact relative to the taxpayer's outof-pocket cost, which is her expenditure of other than borrowed funds. Out-of-pocket cost is the denominator of the fraction that he uses to calculate rates of return, and borrowing causes it to decrease at a higher percentage rate than the numerator (net annual income). ${ }^{106}$ This change in relative impact results from the fact that the tax system generally treats an expenditure of borrowed funds as a cost to the same extent as an expenditure of cash. The rate-of-return analysis, however, treats the two types of expenditures as fundamentally different, with only the latter being counted.

Since the tax system generally treats the use of borrowed funds as equivalent to the use of cash, leverage can enhance the rate of return on out-of-pocket costs even absent any tax preferences. All that is needed to reach this result is a change in the hypothetical so that the underlying asset depreciates, instead of being a perpetual bond. ${ }^{107}$ But it is unclear why only out-of-pocket costs should be included in determining the relevant rate of return. After all, as an economic matter the value of a cost need not be affected by whether or not the taxpayer must pay it out-of-pocket. An obligation to repay $\$ 500$ of principal at some time in the future should be worth exactly $\$ 500$ today if it bears an appropriate rate of interest. ${ }^{108}$

${ }^{105}$ Andrews, Basic Federal Income Taxation at 1363 (cited in note 16).

${ }^{108}$ Thus, in the second hypothetical above, borrowing $\$ 500$ at 12 percent decreases the denominator by 83.3 percent (from $\$ 600$ to $\$ 100$ ), while the numerator decreases by only 50 percent (from $\$ 72$ to $\$ 36$ ).

${ }^{107}$ For example, assume that a taxpayer in the 40 percent bracket pays $\$ 1,000$ in exchange for four annual payments of $\$ 400$. Assume further that the expenditure is amortized for tax purposes over four years under an economically accurate method that provides for a first-year deduction of $\$ 200$. See Chirelstein, Federal Income Taxation at 137-39 (cited in note 10), describing the sinking fund method of depreciation under which deductions are "back-loaded" or greater in the later years of an asset's useful life. If the taxpayer pays cash, his out-of-pocket cost in Year 1 (after benefiting from the deduction) is $\$ 920$, and his aftertax cash return is $\$ 240$. This amount is 26.1 percent of his out-of-pocket cost. However, if the taxpayer borrows $\$ 500$ at 12 percent, his out-of-pocket cost is $\$ 420$, and his after-tax cash return is $\$ 204$. Thus, leverage increases the after-tax cash return to 48.6 percent of the out-of-pocket cost, even though the transaction is taxed appropriately (from a Haig-Simons standpoint) in all respects. Leverage increases the after-tax cash return on out-of-pocket costs even if one charges the $\$ 200$ amortization deduction against the cash return instead of out-of-pocket cost. If so treated, without borrowing the taxpayer is $\$ 1,000$ out-of-pocket and has an after-tax return of $\$ 120$, or 12 percent. With borrowing, the taxpayer is $\$ 500$ out-ofpocket and has an after-tax return of $\$ 84$, or 16.8 percent.

${ }^{108}$ The use of borrowed funds is equivalent to the use of cash if the borrower must repay all debts in full eventually, has unlimited borrowing capacity at the same interest rate, and need not worry about risk. Because these assumptions are not entirely realistic, financial investors at times regard debt and equity investments as somewhat different and 
Thus, the Andrews analysis, as applied to support selective limitations, provides an incomplete picture. It does not establish that leverage makes tax-favored investments more abusive unless one assumes that costs paid through the use of borrowed funds per se are not economically relevant. Taken to this length, the view is not economically defensible.

If a taxpayer is certain to make a particular investment, his use of either debt or equity to finance it should be of little consequence to the tax system, even if the choice of financing affects his cash rate of return. ${ }^{109}$ Again, deducting interest payments does not reduce taxable income any more than foregoing taxable income from alternative uses of one's cash. The only tax reason for objecting per se to leverage is that it increases the amount that one can spend. ${ }^{110}$ One's cash plus credit always equals or exceeds one's cash. The excess is particularly great if one can borrow against the asset being purchased. Thus, leverage increases the amount that one can spend on tax-favored investments.

Yet increased spending capacity is not bad in itself. ${ }^{111}$ The more capacity one has, the more one may spend for all purposes, taxable as well as tax-favored. The additional investments that are made possible by borrowing are not necessarily worse than those the taxpayer would make if restricted to his cash resources. Thus, the argument that leverage is inherently abusive or problematic

rely on rate of cash return analyses similar to that developed by Professor Andrews in order to determine optimal debt-equity mixtures. These analyses may at times show that debt financing increases the cash return from an investment, even on a pre-tax basis. See Koppelman, $61 . S$ Cal L Rev at 1159 (cited in note 53). Yet the difference between debt and equity investments can easily be overstated, given that they both generally represent true economic costs.

${ }^{108}$ However, economic or social policy goals that underlie the enactment of a preference may be affected by the taxpayer's form of investment. For example, a preference that is designed to increase net saving may fail to the extent that investments made by reason of the preference are debt-financed. See Koppelman, $61 \mathrm{~S} \mathrm{Cal} \mathrm{L} \mathrm{Rev} \mathrm{at} 1194$ (cited in note 53).

${ }_{110}$ The use of leverage can create measurement problems for the tax system. Asserted liabilities with respect to borrowed funds may be incorrectly stated (and in many cases overstated). Consider, for example, a nonrecourse purchase money mortgage (one which the borrower is not personally liable to repay) in an amount greater than the value of the purchased property. In such a case, given the lack of personal liability, the true repayment cost to the taxpayer cannot exceed the value of the property and thus is worth less economically than the face amount of the debt. Moreover, in a purchase transaction, taxpayers can change the amount nominally borrowed by misallocating payments of interest and repayments of principal. See $\$ \S 1271-1275$ (original issue discount rules). However, anti-leverage selective limitations go well beyond identifying and responding to the abuse cases.

111 At the macroeconomic level, borrowing simply facilitates transactions generally, by directing cash to those who will pay the most for it. One reason for objecting to this that is beyond the scope of this article is the goal of reducing taxpayer spending so as to increase saving. 
because of its effect on rates of return cannot withstand scrutiny.

\section{A Second-Best Approach: The Effect of Selective Lim- tations on Horizontal Equity and Allocative NeUtrality}

\section{A. Adopting a Second-Best Approach}

The preceding section has shown that selective limitations cannot definitively be assessed through the application of first-best normative principles without considering aggregate empirical effects. After discussing the importance and proper scope of secondbest analysis, this section explores the first-best ideals that underlie adherence to the Haig-Simons definition of income. It then conducts an extensive theoretical analysis of the aggregate effects of preferences on proximity to these first-best ideals. ${ }^{12}$ This is followed by a second-best analysis of selective limitations, which examines their effect on proximity to the first-best Haig-Simons ideals after taking into account the effects of preferences. Finally, the section concludes by considering the application of selective limitations first to "good" preferences and then to tax benefits that are not preferences.

Only a second-best approach that compares the benefits and costs of selective limitations can illuminate the underlying issues. Yet use of a second-best approach to assess selective limitations is not without risk. The theory of the second-best suggests radical skepticism, not just about piecemeal reform, but about basic knowledge. Once one starts applying second-best considerations, where does one stop? Any conclusion that is valid inside a limited sphere can always be challenged from outside. Under the theory of the second-best, one may not know anything unless one knows everything. ${ }^{113}$

112 My second-best analysis will apply the Kaldor-Hicks standard of optimality, in that it will require a showing only of aggregate gain, without requiring that all "losers" be compensated in moving from one state of affairs to another. See Jules L. Coleman, Efficiency, Utility, and Wealth Maximization, 8 Hofstra L Rev 509, 513-14 (1980) (comparing KaldorHicks efficiency to Pareto optimality).

${ }^{113}$ As an example, consider the merits of a tax preference under the assumption that, for reasons of fairness and/or efficiency, all economic income should be taxed equally. In an otherwise first-best world (i.e., given no other distortions), the preference should be repealed. In a second-best world, however, one can argue that the preference is justified as a response to other divergences from the Haig-Simons definition of income. If this is refuted, one can argue that the preference is justified by the failure of Haig-Simons to reach economic values that are not measurable in fair-market-value terms, e.g., consumer surplus and the psychic value of leisure. Even if this is refuted, one can argue that the preference offsets distortions outside the income tax system, e.g., externalities within the national or world economies. See Edward A. Zelinsky, Efficiency and Income Taxes: The Rehabilitation of 
Some commentators have noted the popularity of paying lip service to the theory of the second-best while "more or less brazenly" continuing to follow the piecemeal principle. ${ }^{114}$ This "brazen approach" is unavoidable when one cannot detect or quantify all possible distortions that may interact with each other; it is preferable to what has been described as "standing by and sadly sucking our thumbs under the sign of second best." 115

Accordingly, the analysis in this section will be "brazen" in a critically important respect. It will examine the second-best implications of selective limitations, not in light of all distortions, but only in relation to a Haig-Simons baseline that most of the section assumes to represent the proper normative standard. My analysis will generally disregard second-best challenges both to that baseline itself and to the efficacy of moving closer to the baseline in piecemeal rather than comprehensive fashion. In other words, it will assume both that all preferences affected by selective limitations are bad, and that the repeal or reduction in scope of any particular preference would be desirable. Moreover, it will disregard the application of selective limitations to tax benefits that are not preferences. The goal will be to illuminate how, if one accepts these assumptions, one should view selective limitations.

The assumptions plainly are disputable in second-best terms. Indeed, the theory of the second-best almost proves that they are not universally correct. Yet adopting them is not wholly arbitrary. To begin with, given the popularity of the Haig-Simons standard, it may be useful simply to examine the implications of that standard. Moreover, the view that preferences ought to be repealed, even one at a time, may well be correct in many cases, even if externalities and second-best problems prevent it from being universally true. Thus, a second-best analysis that starts from HaigSimons assumptions may be correct on broader second-best grounds in particular cases-indeed, in many cases if many preferences should be repealed.

Further, concern for intellectual coherence supports structuring the analysis this way. Selective limitations on their face respond to provisions that, from a Haig-Simons perspective, are dis-

Tax Incentives, 64 Tex L Rev 973, 1005-08 (1986). At this level of generality, proof or disproof may be impeded by the need to make complex factual assumptions and numerous value judgments before arriving at an answer.

114 Rowley and Peacock, Welfare Economics at 21 (cited in note 67).

11 E.J. Mishan, Second Thoughts on Second Best, 14 Oxford Econ Papers 205, 214 (1962). 
tortions. They deny deductions as an indirect means of addressing income exclusions or deferrals. Thus, a Haig-Simons assessment that does not consider whether they are second-best completely misses the point.

Nonetheless, near the end of this section I will examine the consequences of abandoning the assumption that preferences are undesirable (and that selective limitations apply only to preferences). Having considered what impact selective limitations have on "bad" preferences, one can assess the provisions' effects both on "good" preferences and on tax benefits that are not preferences or otherwise associated with the under-measurement of income.

\section{B. Reasons for Conformity to the Haig-Simons Definition of Income}

The Haig-Simons definition of economic income provides a normative model for income taxation if one believes that the same rate (or rates) of tax should apply to the different types of income the definition identifies. This belief generally is founded on two grounds, which broadly can be denominated "fairness" and "efficiency."

\section{Fairness.}

a. Horizontal equity. The most commonly advanced ground for following the Haig-Simons definition is "fairness" in the sense of horizontal equity. Henry Simons argued that persons in like circumstances should pay a like amount of taxes, and that pretax economic income was the proper basis for determining likeness. ${ }^{116}$ Others similarly have described the tax system as equitable only insofar as it "treats equals equally," 117 with equals defined as those with the same ability to pay, ${ }^{118}$ and with ability to pay defined in terms of household income. ${ }^{119}$

In determining whether the tax system treats equals equally, the most direct and literalistic approach would be to examine actual taxes paid in relation to pretax income, while ignoring the tax

116 Simons, Personal Income Taxation at 30-31 (cited in note 5).

117 Boris I. Bittker, Equity, Efficiency, and Income Tax Theory: Do Misallocations Drive Out Inequities?, 16 San Diego L Rev 735, 735 (1979).

${ }^{118}$ See Walter Hettich and Stanley Winer, Blueprints and Pathways: The Shifting Foundations of Tax Reform, 38 Natl Tax J 423, 424-26 (1985) (describing the premises of the Haig-Simons approach).

119 See Treasury Department Report to the President, 1 Tax Reform for Fairness, Simplicity, and Economic Growth 5 (CCH, Nov 27, 1984) ("Treasury I"). 
system's indirect effects. However, a broader and more sophisticated approach would attempt to look at the net effect of the income tax system on after-tax income. Under this approach, the relevant comparison is between taxpayers whose incomes would be equal if the tax system did not exist. ${ }^{120}$

The broader approach is hampered by difficulties, not only of measurement, but more fundamentally of definition. For example, in determining income levels in the absence of a tax system we presumably do not mean to assume either a state of anarchy or a world in which the government spends money without having any revenue sources. Nor do we mean to disregard income from the performance of tax functions (for example, the salaries of tax lawyers and IRS revenue agents). Ultimately, a broad assessment of the tax system's aggregate effects on income may be based on something as fictitious and unknowable as the political philosopher's state of nature.

In part for these reasons, analysis of horizontal equity generally follows the narrower approach and looks only at taxes paid in relation to pretax income. In one sense, however, commentators often follow a somewhat broader approach. They commonly consider preference capitalization, or the incurring of what can be termed implicit taxes. Preference capitalization is a result of market responses to the prescribed under-measurement of taxable income from a particular investment. Consider tax-exempt bonds. If such bonds offered the same pretax yield as taxable financial instruments (adjusting for risk), then bondholders would benefit after tax by the full amount of the tax avoided and thus would do much better than other investors. For example, if all $\$ 100$ bonds (taxable and tax-exempt) paid 10 percent interest, and the only applicable tax rate was 30 percent, holders of tax-exempt bonds would retain $\$ 10$ after tax while holders of taxable bonds would retain only $\$ 7$ after tax.

However, investors are too knowledgeable, flexible, and interested in maximizing after-tax profit for this state of affairs to prevail. The preference results in increased demand for tax-exempt bonds at the expense of demand for alternative uses of funds. An

${ }^{120}$ Another type of broad approach would look at taxpayer opportunities, not actual results. This approach would treat equally two taxpayers with the same opportunity to benefit from a preference, even if only one actually seized the opportunity. Thus, $A$ would be considered no better off than B if A's tax burden was less simply because A took a greater interest in tax planning. Yet the approach overlooks that what seems to be the same opportunity may in fact not be, if taxpayers differ in inclinations or aptitudes and some types of inclinations or aptitudes are rewarded by the tax system more than others. 
increased number of bonds are sold, but at a reduced yield. Prospective buyers bid away a significant portion or even all of the after-tax benefit. ${ }^{121}$ This reduction in yield, which can be measured by comparing the yields from similar taxable bonds, is termed an implicit tax. For example, if taxable $\$ 100$ bonds yield $\$ 10$ before tax and tax-exempt $\$ 100$ bonds yield $\$ 8$, then the implicit tax on the tax-exempt bonds is $\$ 2$. The conventional scholarly standard for assessing horizontal equity takes account of implicit taxes. ${ }^{122}$ For convenience I will begin by applying the conventional standard, although I will later modify the standard to take account of the effect of preference capitalization on those benefitting from an implicit tax, such as bond issuers.

b. Vertical equity. A second kind of fairness relevant to a Haig-Simons analysis is vertical equity, which concerns the relationship of the tax burdens placed on those with different incomes. ${ }^{123}$ Exactly what constitutes vertical equity is the subject of some dispute, with proportional and progressive tax systems being the prinicipal competing conceptions. Whichever notion (and whatever degree of progression) is adopted, the Haig-Simons approach has at least some tendency to promote vertical equity: one cannot establish a particular relationship between the taxes paid by those with different incomes without first achieving a fairly comprehensive definition of income-which Haig-Simons provides. But Haig-Simons does not tell us how tax liability should vary with income-whether tax rates should be proportionate or progressive and; if progressive, to what degree. (Such decisions are considered appropriately left to the political process.) ${ }^{124}$ And as it turns out, a progressive conception of vertical equity would seem frustrated by deviation from Haig-Simons in some circumstances while advanced in others.

Income exclusions or deferrals, for example, may partially counteract a progressive tax system by providing a greater reduction in tax liability for persons in higher tax brackets. Moreover, tax favored investments may favor higher-income taxpayers be-

${ }^{121}$ See Chirelstein, Federal Income Taxation at 345 (cited in note 10); Warren, 38 Tax Lawyer at 563-64 (cited in note 13).

${ }^{122}$ See, for example, Chirelstein, Federal Income Taxation at 345-49 (cited in note 10); Bittker, 16 San Diego L Rev at 739 (cited in note 117); Warren, 38 Tax Lawyer at 559-60 (cited in note 13); Warren, 59 Taxes at 990-91 (cited in note 45); David J. Shakow, Confronting the Problem of Tax Arbitrage, 43 Tax L Rev 1, 2-4 (1987).

${ }^{123}$ See, for example, Bittker, 16 San Diego L Rev at 735-36 (cited in note 119); Hettich and Winer, 38 Natl Tax $J$ at 424 (cited in note 118).

124 Id. 
cause such persons have more liquidity, and access to better legal advice; ${ }^{128}$ In other cases, however, departure from Haig-Simons seems to promote a progressive notion of vertical equity. For example, advocates of a progressive tax system might favor imposing an excise tax on yacht ownership (assuming a political constraint on changing marginal rates).

In sum, the relationship between Haig-Simons and any conception of vertical equity is relatively weak. The fairness grounds for Haig-Simons income taxation must largely be based on horizontal equity.

\section{Efficiency.}

a. Allocative efficiency. A second ground for following the Haig-Simons definition is allocative efficiency. The argument begins with the assumption that market allocations of resources, as determined by pretax profitability, generally are optimal (or, at least, better than the alternatives likely to be achieved by the political process). It is further assumed that taxpayers generally seek to maximize after-tax profitability. The argument proceeds that, if income from-one investment is taxed differently than income from another, the signals sent to investors by the marketplace are altered. Taxpayers will prefer tax-favored investments even when such investments are relatively unprofitable on a pretax basis. The consequent diversion of capital and labor from their most productive uses results in "lower productivity, lost production, and reduced consumer satisfaction."126

b. Overhead efficiency. A second type of efficiency relevant to a Haig-Simons analysis involves minimizing the tax system's overhead costs-the resources expended in tax planning, compliance, and administration. The Haig-Simons definition improves over-

${ }^{125}$ A preference does not undo rate progressivity if incurred solely by taxpayers in the highest rate bracket and if its value is completely capitalized for those taxpayers. Moreover, preferences can be designed to be progressive, through phaseouts as taxable income increases, for example, or through the use of low dollar ceilings on the amount of benefit from a particular preference.

128 Treasury $I$ at 4 (cited in note 119). In many respects, the Haig-Simons approach may itself cause allocative inefficiency, since for administrative reasons it disregards certain forms of value (the imputed value of leisure, for instance). Moreover, an income tax may favor consumption over saving. See William D. Andrews, A Consumption-Type or Cash Flow Personal Income Tax, 87 Harv L Rev 1113, 1125 (1974). Even if these omissions are unavoidable, they arguably call for second-best responses to reduce their distortive effect-for example, lower taxes on income such as compensation that is relatively leisuresubstitutive. While I am disregarding these distortions in order to simplify the present analysis, I recognize that they are significant. 
head efficiency to the extent that it reduces incentives for tax planning. There will be less need for tax lawyers (and tax professors) if all income is taxed equally. On the other hand, accurate income measurement may require complex rules that increase compliance and administrative costs. Consider, for example, the increased complexity that would result from repealing the realization requirement and requiring annual valuations of all property. In light of such complexity, the relationship between Haig-Simons and overhead efficiency, as between Haig-Simons and vertical equity, is relatively weak.

3. Preference capitalization and the tradeoff between equity and efficiency.

a. Is equity more important than efficiency? There has long been consensus among tax scholars that both fairness and efficiency are desirable ends. Even Henry Simons, while principally concerned with horizontal equity, believed that the income tax system should "alter as little as possible the course that would have been followed, if there had been no such taxes. ..."127 The focus on allocative efficiency has increased since Simons's day, due to the popularity of economic analysis and the tendency of reduced rate graduation to improve the adequacy of implicit taxes. ${ }^{128}$ Despite the consensus that it is important, ${ }^{129}$ however, allocative efficiency somehow has remained the bastard child of tax policy analysis in much discussion of preferences and selective limitations.

One might ask why it is necessary to weigh fairness against efficiency. After all, both concerns are thought generally to support conformity to the Haig-Simons approach. The answer is that fairness and efficiency suggest different views on preference capitalization..As discussed above, preference capitalization promotes horizontal equity (as conventionally defined, disregarding the effect of an implicit tax on its beneficiaries such as tax-exempt bond issuers), since it causes investors to incur implicit taxes as substitutes for the direct taxes that they otherwise would owe. Under efficiency analysis, however, preference capitalization and implicit

${ }^{227}$ Simons, Personal Income Taxation at 213 (cited in note 5). Simons never had to decide how to evaluate preferences that were only inefficient, rather than unfair, because he understood that under the steeply graduated marginal rates of his day, high-bracket taxpayers would never pay enough implicit tax to satisfy equity concerns. Id at 173.

${ }^{128}$ See Chirelstein, Federal Income Taxation at 347-51 (cited in note 10).

129 Id at 348-49; Warren, 38 Tax Lawyer at 569 (cited in note 13); Shakow, 43 Tax L Rev at $20-22$ (cited in note 122 ). 
taxes appear in a very different light. Again, declines in pretax yields from tax-preferred investments generally are accompanied by increases in the quantity of such investments held in the economy. Thus, to the extent that preference capitalization reduces the horizontal inequity of a preference, it does so at the cost of increased allocative inefficiency.

For this reason, the horizontal equity and the allocative efficiency of a preference appear inversely related. As marketplace responses increase, the preference becomes more fair but less efficient. As marketplace responses decrease, the preference becomes more efficient but less fair. ${ }^{130}$ If fairness and efficiency were viewed as equally important, then the magnitude of marketplace responses to preferences might seem almost irrelevant. Preference capitalization would merely change the ratio between two harms when it converted horizontal inequity into allocative inefficiency. Yet the frequent custom in tax scholarship has been to treat preference capitalization, and the resulting conversion of unfairness into inefficiency, as an unmitigated good.

This custom attaches great importance to Congress's apparent intent in enacting various preferences. Professor Warren, for example, argues that when the capitalization of preferences deliberately enacted by Congress causes a transaction to yield a pretax accounting loss, the preferences are fulfilling intended allocative goals; consequently, he argues, the preferences should not be limited by a requirement of pretax profit. ${ }^{131}$ In his view, only preferences that appear to be inadvertent should be limited when they are used in intentional loss transactions. ${ }^{132}$

But Professor Warren's analysis conflates two separate issues: the intentionality of a preference and the exact nature of that intention. Without explaining why, Professor Warren assumes that Congress always operates on the principled ground of social policy (aiming to change the allocation of resources among sectors of the economy), rather than sometimes acting with the more mundane purpose of benefiting particular taxpayers. Moreover, he assumes that one must defer to presumed congressional policies regarding resource allocation, ${ }^{133}$ despite his overt skepticism that these poli-

130 See Bittker, 16 San Diego L Rev at 738 (cited in note 117).

132 Warren, 59 Taxes at 989-92 (cited in note 45) (arguing that the pretax accounting profit requirement fails to draw intellectually consistent distinctions, and if applied at all should be limited to transactions that violate the congressional intent behind the preference).

132 Id at $989-90$.

${ }^{233}$ See id at $990-92$. 
cies are well-founded. ${ }^{134}$ Yet the claim that one should defer to Congress's presumed allocative policies is controversial, and if deference is not required there may be no reason automatically to favor preference capitalization.

In the context of the pretax accounting profit requirement, Professor Warren's deference to presumed congressional intent may be justified; the requirement is a judicial doctrine, and thus is presumably constrained in its application by expressed legislative intent. The other selective limitations discussed in this article are statutory, however, and thus are not constrained by the legislative intent underlying the preference. Many commentators nonetheless defer to Congress's presumed allocative intent in enacting preferences and embrace the view that preference capitalization is desirable when it converts unfairness into inefficiency. ${ }^{135}$ Such analyses repeatedly fail apparently to examine or defend the premise that preference capitalization is desirable.

Professor David Shakow may have identified the reason for this bias in commenting that equity is more of a lawyer's concern while efficiency is more of an economist's. ${ }^{136}$ It would be understandable that tax commentators trained in the law would prefer to focus on equity, even at the risk of ignoring issues they concede to be important. Their support of the apparent conversion of inequity into inefficiency through preference capitalization may also reflect discomfort with exceeding their area of expertise by considering what might be regarded as the mere politics of resource allocation. ${ }^{137}$ But why should an aversion to political issues permit tax scholars to raise issues of fairness but not efficiency?

The implicit (if unexpressed) rationale for ignoring efficiency may be that Congress's political choices regarding resource allocation raise issues that depend on nontax considerations and that ultimately are somewhat indeterminate. This rationale plainly draws on realistic concerns about the assessment of allocative efficiency. Market distortions outside of the tax system may provide second-best justifications for preferences, and yet the amount and

134 Id.

${ }^{135}$ See, for example, id at 989-92; Mundstock, 29 Tax Notes at 1258 (cited in note 61); Shakow, 43 Tax L Rev at 21-22 (cited in note 122). Johnson accepts the "intent" argument insofar as he tries to show that leverage creates unintended and enhanced tax benefits. Johnson, 6 Va Tax Rev at 139-41 (cited in note 18). Cooper similarly argues from the unexamined premise that tax benefits are more justified in the presence of a high degree of preference capitalization. Cooper, 85 Colum L Rev at 705-07, 714-15 (cited in note 18).

${ }^{136}$ Shakow, 43 Tax L Rev at 16 (cited in note 122).

${ }^{137}$ See Louis Eisenstein, The Ideologies of Taxation 210-11 (Ronald Press, 1961). 
direction of such distortions are difficult to measure. Thus, in weighing efficiency tax scholars may indeed risk leaving their area of expertise and losing the ability to derive clear answers. But the very same point can be made about fairness: it turns on indeterminate nontax considerations to at least the same extent as efficiency.

For example, a congressional policy of imposing relatively low taxes on a particular group could be based on a number of different findings: that the group received lower-than-average benefits from government spending; that it contributed to national security; or that it was unusually virtuous. These issues are as extrinsic to the tax system, and perhaps even more indeterminate, than issues of broad economic efficiency. ${ }^{138}$ Thus, diffident scholars should probably define fairness as set by governmental policy. Then the objective would be satisfied only when there was no preference capitalization, and Congress succeeded in conveying lasting aftertax benefits to favored groups.

There is no factual basis for concluding that Congress's actual policy goals have more to do with managing the economy than with benefiting particular individuals or groups. Indeed, most sophisticated observers of the legislative process believe the contrary: that preferences typically are designed to reward well-organized interest groups, and that many of the broad economic policy goals stated in legislative histories are largely rationalizations. ${ }^{139} \mathrm{~A}$ belief in broad economic policy goals is further undermined by the manner in which expressed policies frequently conflict with each other, thus tending to cancel out any broader allocative effects while still directing benefits (at least in the short term) to particular constituencies. ${ }^{140}$

In any case, Congress's motives in enacting preferences should not matter for purposes of analysis (except insofar as Congress may be less likely to make good allocative choices if it is not even trying to do so). Commentators are free to question the intended

${ }^{198}$ See Walter J. Blum and Harry Kalven, Jr., The Uneasy Case for Progressive Taxation 19 U Chi L Rev 417, 451-55 (1952) (discussing the difficulty of comparing the benefits that different individuals or groups receive from government).

139 See Eisenstein, The Ideologies of Taxation at 199-223 (cited in note 137); Jeffrey H. Birnbaum and Alan S. Murray, Showdown at Gucci Gulch: Lawmakers, Lobbyists, and the Unlikely Triumph of Tax Reform 285-91 (Random House, 1987); Richard L. Doernberg and Fred S. McChesney, Doing Good or Doing Well? Congress and the Tax Reform Act of 1986, 62 NYU L Rev 891, 901-04 (1987). Birnbaum and Murray claim, while Doernberg and McChesney dispute, that the 1986 Act was an exception to "politics as usual," but both pairs of authors agree that tax legislation usually is designed to benefit particular groups.

${ }^{140}$ See Victor Thuronyi, Tax Expenditures: A Reassessment, 1988 Duke L J 1155, 1161 (noting inconsistent policies toward dairy farming). 
as well as the incidental effects of legislation. And the assumption that capitalized preferences generally reduce efficiency may be just as reasonable as the assumption that uncapitalized preferences generally reduce fairness. Thus, one should not welcome preference capitalization on the ground that it purportedly furthers congressional intent.

A final conceivable reason for preferring fairness to efficiency is the intuition, or value judgment, that fairness is more important. Perhaps the scholars who pay lip service to both actually value fairness more highly, although without saying why. Ultimately, of course, the belief that fairness is more important than efficiency cannot be evaluated without descending into rank subjectivity. Still, it is worth noting that some of the more obvious grounds on which such a value choice could be based, even if generally defensible, do not apply in the particular context of the Haig-Simons approach to income taxation.

For example, efficiency theory is often criticized for promoting mere wealth maximization, and for ignoring that not all goods are measured properly by the market, or are reducible to dollar terms. ${ }^{141}$ Whatever the criticism's import for efficiency theory generally, it does not support giving greater weight to horizontal equity than to efficiency in the income tax context. After all, the fundamental premise of horizontal equity is that similarly situated taxpayers should bear the same tax burden, with both the taxpayers' situations and the tax burden measured in dollar terms. Accordingly, the rejection of dollar measurement as a normative standard impeaches both the efficiency and the fairness rationales for Haig-Simons income taxation. Similarly, even if one accepts that distributing economic resources fairly is more important than maximizing aggregate social wealth, it should be noted that HaigSimons promotes horizontal equity more than vertical equity. The principle that those with equal incomes should pay equal taxes does not reach issues of broader distributive justice.

Accordingly, there may be no good reason for considering fairness more important than efficiency in assessing preference capitalization. In my analysis of whether selective limitations may be second-best from a Haig-Simons perspective, I will assume that fairness and efficiency are equally important. I will treat the HaigSimons definition as designed to aid the tax system in (1) imposing equal taxes on taxpayers with equal incomes, and (2) avoiding

141 See Arthur Allen Leff, Economic Analysis of Law: Some Realism About Nominalism, $60 \mathrm{Va} \mathrm{L}$ Rev 451, 454-59 (1974) (discussing normative influences in valuation). 
changes in the resource allocations that would prevail if taxpayers were guided by pretax profitability.

b. Does preference capitalization convert inequity into inefficiency? As suggested in the previous section, converting inequity into inefficiency may be undesirable or at best neutral. Preference capitalization, however, may not achieve even that much. The premise that it increases horizontal equity, considered in the broadest sense, is highly disputable. Does preference capitalization cause after-tax benefits to disappear, or does it merely shift the benefits from one person to another?

Suppose that Congress enacts a refundable tax credit of $\$ 3$ per widget sold, and the preexisting market price for widgets was $\$ 10$. Assume for the moment that the credit is provided to widget sellers. In that case, the preference would be considered fully capitalized if the tax benefit shifted entirely to widget buyers, and the market price ultimately declined to $\$ 7$ (thus leaving sellers with the same after-tax return of $\$ 10$ per widget that they received prior to enactment). Now assume instead that the credit is provided to buyers. In that case, full preference capitalization would be defined as the situation in which the tax benefit shifted entirely to sellers, and the market price increased to $\$ 13$.

If either kind of full preference capitalization occurs, someone is still benefiting. The only change resulting from preference capitalization is the identity of the beneficiary. If the credit is provided to sellers and the market price for widgets declines to $\$ 7$, then a windfall of up to $\$ 3$ per widget accrues to buyers. ${ }^{142}$ If the credit is provided to buyers and the market price increases to $\$ 13$, a similar windfall accrues to sellers.

These windfalls are ignored in conventional tax analysis because, as a practical matter, it may be difficult to determine the price at which an asset would have sold in a world without the tax preference. For example, the 1989 value of a particular real estate item could not be determined in the absence of the various real estate tax preferences, even if one knew an actual market value. Nonetheless, the difficulty of accounting for windfalls does not justify ignoring them when analyzing horizontal equity. After-tax benefits do not disappear simply by being shifted to a form that is "off the books." In light of the windfall effect on indirect benefi-

142 The windfall would equal $\$ 3$ for any buyer who would have paid $\$ 10$ for a widget absent the preference. A buyer who would not have bought a widget at that price would arguably still benefit by the difference between $\$ 7$ and the maximum price he would have paid. 
ciaries, preference capitalization may provide no more than an illusion of horizontal equity. It does not eliminate the benefit of a preference, but instead merely shifts its incidence between buyers and sellers of tax-favored assets. ${ }^{143}$

\section{The Extent of Preference Capitalization}

Whatever the significance of preference capitalization for fairness and efficiency, one must know something about its magnitude to evaluate the impact of selective limitations. At first glance, full capitalization of the value of preferences may seem economically inevitable. After all, it is widely accepted that "competitive capital markets [] create pressure toward equivalence of after-tax returns for all capital income, taking into account differences in risk."144 Yet it is also recognized that a number of factors impede full capitalization.

\section{Analysis in the existing literature.}

Under the more steeply progressive marginal rate structure that prevailed before the 1986 Act, implicit taxes appeared to be inadequate. For example, between 1960 and 1977 the implicit tax on tax-exempt bonds was well under half of the top marginal rate. ${ }^{145}$ Thus, tax-exempt bonds provided an after-tax windfall for taxpayers in high rate brackets. This phenomenon was explained on the ground that market forces caused the equalization of aftertax yields only for taxpayers in the lowest rate bracket to which tax-exempt bonds were commonly sold. For example, if issuers could not meet their sales targets without attracting investors in the 30 percent bracket, they would need to offer at least 70 percent of the pretax return available from similar but taxable bonds, thus providing a windfall to taxpayers in the 50 percent bracket. ${ }^{146}$

However, the view that full capitalization is the norm for bonds, absent disparities resulting from rate progressivity, has been vindicated by evidence arising since institution of the relatively flat rate structure established by the 1986 Act. For many

${ }^{143}$ Preference capitalization may nonetheless improve equity for non-Haig-Simons reasons. For example, one might prefer to have the benefits of the exemption for municipal bond interest inure broadly to persons in the issuing state, rather than narrowly to a few bondholders.

144 Warren, 38 Tax Lawyer at 564 (cited in note 13). See also Warren, 59 Taxes at 990 (cited in note 45).

${ }^{145}$ See Cooper, 85 Colum L Rev at 699 (cited in note 18).

${ }^{146}$ See Chirelstein, Federal Income Taxation at 345-51 (cited in note 10). 
taxpayers, tax-exempt bonds now offer about the same after-tax returns as similar taxable financial instruments. ${ }^{\mathbf{1 4 7}}$

Given this evidence about tax-exempt bonds, one might expect widespread full preference capitalization under the current rate structure. ${ }^{148}$ However, commentators have identified a number of factors that continue to impede full preference capitalization. These factors include market inefficiency, variations in the elasticity of the supply of tax-favored assets, the lapse of time before markets adjust to tax law changes, and the existence of international markets that set prices independent of United States tax considerations. ${ }^{149}$ In addition, commentators have identified a situation in which no preference capitalization is to be expected: the case of pure tax arbitrage.

Tax arbitrage may be defined as the reciprocal borrowing and lending of money to give at least one party tax-exempt interest income and deductible interest expense. ${ }^{150}$ For example, assume that a taxpayer both (1) borrows $\$ 2,000$ from a bank, giving rise to deductible interest expense, and (2) purchases a $\$ 2,000$ individual retirement account (IRA) from the same bank, giving rise to taxfree interest income. While the taxpayer's taxable income will decline by the amount of interest expense, there may in fact be little or no change in his economic position or in the net amount and distribution of saving in the economy. After all, little has happened beyond the establishment of two offsetting ledger entries. ${ }^{151}$

This lack of aggregate economic change implies a lack of preference capitalization. The value of tax benefits cannot be bid away

147 The yield on AA ten-year general obligation tax-free municipal bonds was $6.55 \%$ on November 17,1989 . The yield on similarly rated $1-10$ year corporate bonds was $8.83 \%$ on the same day, which after adjusting for a $28 \%$ income tax, is $6.36 \%$, or more than $97 \%$ of the tax-exempt yield. Wall Street Journal, page C 18 ("Yield Comparisons") (November 17, 1989).

${ }^{148}$ Whether full capitalization is occurring may be hard to determine empirically with assets other than tax-exempt bonds, because many tax-favored assets lack taxable analogues similar enough to permit the direct comparison of yields possible with bonds. Moreover, even when tax treatment of the same investment changes over time, the price effect may be hidden by contemporaneous nontax changes, as well as by marketplace anticipation of the tax change. See Boris I. Bittker, Tax Shelters and Tax Capitalization, or, Does the Early Bird Get A Free Lunch?, 28 Natl Tax J 416, 417 (1975), regarding the perils that face would-be "early birds" who seek to capture the benefit from tax law changes.

149 Warren, 38 Tax Lawyer at 564-65 (cited in note 13). Koppelman, $61 \mathrm{~S} \mathrm{Cal} \mathrm{L} \mathrm{Rev} \mathrm{at}$ 1184-85 (cited in note 53), mentions several additional factors, such as investor ignorance about the tax laws and basic personal finance, and demand for relatively unprofitable investments for diversification reasons.

${ }^{150}$ See Steuerle, 30 Wayne L Rev at 1004 (cited in note 86); Warren, 38 Tax Lawyer at 565 (cited in note 13 ).

${ }^{161}$ Steuerle, 30 Wayne L Rev at 1005 (cited in note 86). 
absent such change; in the example, the bank is not facing increased demand for the pool of capital that it had prior to the offsetting transactions. Thus, pure tax arbitrage affects horizontal equity but not allocative efficiency. ${ }^{152}$ Even transactions that are not consciously or overtly reciprocal can offset each other in varying degrees, thereby reducing tax liability without significant net economic change. Eugene Steuerle notes that different loans throughout the economy may result only in a more leveraged society, where large groups reciprocally owe each other more, rather than in a society with more (or differently allocated) net saving and investment. ${ }^{153}$

Transactions need not involve leverage in order to resemble pure tax arbitrage by having tax consequences but little or no net economic effect. For example, consider the planning opportunities that would be available to two wealthy taxpayers with sizeable portfolios of publicly traded stock in the absence of the capital loss limitation. Such taxpayers could agree to sell each other all of their depreciated stocks for fair market value at the end of each taxable year. Assuming substantial fluctuations in the value of particular stocks but stability in the aggregate value of the portfolios, each taxpayer could generate substantial tax losses unaccompanied by net economic losses. Moreover, the stock transfers between the two taxpayers might lack broad economic consequences. Of course, the planning opportunity may have induced the taxpayers to increase the size of their stock portfolios. Yet, to the extent that their aggregate holdings did not increase, there would be no significant economic change and, therefore, no preference capitalization. ${ }^{154}$

More generally, whenever tax-motivated transactions lack net economic effect, whether individually or in the aggregate, the related tax benefits will not be capitalized. ${ }^{155}$ However, pure tax arbi-

${ }^{152}$ Pure tax arbitrage may reduce overhead efficiency, by inducing taxpayers to incur increased costs of planning and record-keeping for loan transactions. Pure tax arbitrage also may destabilize the banking system by increasing the amount of finances tied up in interlocking and interdependent loans.

If everyone engaged in an equal amount of pure tax arbitrage, only government tax revenues, rather than horizontal equity, would be affected.

${ }^{153}$ Steuerle, 30 Wayne $L$ Rev at 1005 (cited in note 86).

154 Of course, the benefit of the realization requirement might be capitalized into the prices at which the two taxpayers originally purchased the stocks in their portfolios.

${ }^{155}$ Thus, the use of purely formal planning devices (such as trusts and related party gifts) to reduce one's taxes does not give rise to preference capitalization. See Cooper, 85 Colum L Rev at 701 (cited in note 18). Similarly, Professor Koppelman notes that "status" tax benefits, which base exemption on the identity of the taxpayer or intermediary through which the taxpayer invests, do not involve market responses and thus are not capitalized. Koppelman, $61 \mathrm{~S} \mathrm{Cal} \mathrm{L} \mathrm{Rev} \mathrm{at} \mathrm{1175-76} \mathrm{(cited} \mathrm{in} \mathrm{note} \mathrm{53).}$ 
trage presumably is not an all-or-nothing phenomenon. The degree of aggregate economic response to a tax provision may affect the degree of preference capitalization. Transactions that have only a small aggregate economic effect may give rise to only a small degree of preference capitalization.

In summary, prior commentators have shown a number of reasons why preference capitalization is often incomplete. It may be useful, however, to consider whether there are broader and more general reasons why full capitalization is a limited exception rather than the general rule.

2. Supply, demand, and price effects of preferences.

a. Widgets and bonds. Consider again the example in which the market price for widgets is $\$ 10$ and Congress enacts a refundable credit of $\$ 3$ per widget sold. If the credit is provided to sellers, under conditions of full capitalization the market price of widgets eventually will decline to $\$ 7$. Only a $\$ 3$ market adjustment would leave sellers with the same after-tax return they received before enactment of the preference, while permitting buyers to capture the entire tax benefit. ${ }^{156}$ By contrast, if the $\$ 3$ refundable credit is provided to buyers, then with full capitalization the market price eventually will increase to $\$ 13$. Only a $\$ 3$ adjustment would leave buyers no better off than before and permit the entire tax benefit to be captured by sellers.

Stated this baldly, the belief that full capitalization generally will occur may begin to appear peculiar. Why should the direct recipients of tax benefits be so unsuccessful at retaining any portion of the benefits? Should the buyers and sellers of an asset battle each other in the halls of Congress, each seeking to have a preference granted to the other? Might it not be more reasonable to expect that they will divide the benefit of the preference the same way (depending on market forces), regardless of its direct incidence?

Measuring the expected amount of preference capitalization boils down to predicting the price effects of a preference. Tax policy theory has little to offer on this issue, and it will be useful to consider equilibrium price theory instead. Under standard microeconomic assumptions, the market demand for an item will

${ }^{156}$ See text at note 142 . This is not to say, however, that the benefit is always $\$ 3$. A buyer receives the full $\$ 3$ benefit only if he would have paid $\$ 10$ for the widget. If he would have paid no more than, say, $\$ 8$, then arguably his benefit is only $\$ 1$, and the extra $\$ 2$ is a deadweight loss (disregarding externalities). 
increase gradually as the price decreases. At the same time, the market supply of an item will decrease gradually as the price decreases. Obviously, the amount by which supply and demand change with the price will vary from case to case. However, so long as they both change gradually, a sudden shift in one by reason of a tax preference will have certain predictable effects on the equilibrium price and quantity.

To examine these effects, consider again the widget example. If a $\$ 3$ tax preference for sellers is newly enacted, the supply curve (from the perspective of buyers) should shift downward by exactly $\$ 3$, while maintaining the same slope. Sellers presumably are indifferent whether they receive, for example, $\$ 10$ from a purchaser plus zero from the government, or $\$ 7$ from a purchaser plus $\$ 3$ from the government. ${ }^{157}$ The eventual new equilibrium price, however, will not decline by as much as $\$ 3$ (i.e., to $\$ 7$ ). Supply at $\$ 7$ now equals what was formerly both supply and demand at $\$ 10$. Yet the buyers' demand curve is unchanged, and demand at $\$ 7$ continues to be more than demand at $\$ 10$. Thus, demand exceeds supply at $\$ 7$, and the price must move above $\$ 7$ (increasing the amount supplied and reducing the amount demanded) for it to reach a new equilibrium point.

A similar analysis applies if the preference inures directly to buyers. If buyers are the ones to receive a $\$ 3$ credit, then the demand curve (from the perspective of buyers) will shift by $\$ 3$. The new equilibrium price should be between $\$ 10$ and $\$ 13$, rather than exactly $\$ 13$, since supply exceeds demand at $\$ 13$.

Thus, two results can be predicted regardless who receives the benefit. First, the quantity of widgets sold in relation to other goods should increase as a result of the preference. Second, the after-tax benefit of the preference should be divided between buyers and sellers. Thus, the benefit of the preference should be only partially capitalized. From a Haig-Simons perspective, the preference will adversely affect both allocative efficiency and horizontal equity.

Partial capitalization follows from the assumption that supply and demand change gradually as the price of an item changes. Such change is gradual because both buyers and sellers differ among themselves as to what is the least favorable price at which

${ }^{157}$ In practice, of course, sellers may not be entirely indifferent whether they receive the $\$ 3$ from the government or the buyer; they will prefer payment from the buyer if the tax benefit is less visible, is converted into cash less quickly than a payment from a buyer, or involves higher collection costs (in other words, tax planning). 
it is still worthwhile to buy or sell. They may not all assign the same utility (expressed in dollar terms) to a particular item. Moreover, they individually assign varying marginal utilities to varying quantities of an item, and thus purchase different amounts at different prices. As the price of an asset gradually increases, therefore, more and more buyers switch their decision from "buy" to "no-buy" (or reduce the amount of their purchases). For similar reasons, as the price gradually increases, more and more sellers switch their decision from "no-sell" to "sell" (or decide to sell more). Yet there is no reason to expect that an enormous number of persons will change their decision at exactly the same point.

This explains why the benefits from tax-exempt bonds have, under the newly flat marginal rates, been almost fully capitalized. In general, tax-exempt bonds are merely an income stream (with particular maturity dates and risk attributes). Moreover, they are only one type of income stream. Taxable financial instruments are substantially similar in all economically relevant respects (other than the tax exemption, of course). As a result, buyers in the taxexempt bond market can be expected to act far more alike than those in the markets for most other assets. Many of them may shift their decision from "buy" to "no-buy" at exactly the same price: just below the break-even point, the price at which the return equals the after-tax return from similar but taxable financial instruments. ${ }^{158}$ Thus demand for tax-exempt bonds should decline quite drastically at the break-even point.

Furthermore, in contrast to a huge potential demand, the taxexempt bond market has a sharply constrained supply. Most borrowers cannot offer an interest exemption to prospective lenders. Only state and local governments can issue tax-exempt bonds. ${ }^{150}$ As a result of these features of the tax-exempt bond market, the demand by investors may substantially exceed the supply offered by issuers at the break-even point. But as soon as the price exceeds the break-even point, demand may decline so sharply as to be less than supply. Accordingly, an issuer may find it most profitable to sell bonds at or near the price at which they provide the same return as taxable financial instruments. An issuer need not offer sig-

168 Moreover, the utility that one assigns to different quantities of tax-exempt bonds should be relatively constant, varying only to the extent dictated by the risk-spreading goal of investment diversification.

159 To some extent, state and local governments can in effect "lend" the exemption to certain local businesses, sometimes constrained by volume ceilings. See $\S \S 103,141,146,147$. 
nificantly higher yields in order to sell all of its bonds. ${ }^{160}$ Yet it cannot offer significantly lower yields without losing too much sales volume.

Thus, at or near the break-even point there is unsatisfied demand. Without having to increase yields, issuers could sell more bonds if their borrowing needs increased. In contrast to the usual case, this unsatisfied demand does not chase prices to a higher level at which equilibrium is restored. Instead, the equilibrium price remains at the break-even point, and a portion of the demand at that price simply remains unsatisfied. The pricing of taxexempt bonds at the break-even point permits the value of the interest exemption to be fully capitalized. Bondholders receive the same after-tax return as that available from similar but taxable financial instruments, and the benefit of the preference shifts entirely to the issuers.

Tax-exempt bonds are quite unusual since they are just a relatively predictable income stream, and there is no reason to conclude from this example that the value of preferences is generally fully capitalized. However, if all capital investments are as mutually interchangeable as are tax-exempt bonds with taxable financial instruments, then full preference capitalization may occur in all markets for capital assets. Buyers and sellers of capital assets may act sufficiently alike for all to have equilibrium prices equal to their break-even prices (the prices at which, despite differing degrees of tax preference, they offer identical after-tax returns at any given level of risk).

It seems unlikely, however, that capital assets are as interchangeable as financial assets like tax-exempt bonds. The former are probably more likely to give rise to differing income expectations, or to reflect differences in personal taste and income-producing aptitude. Buyers and sellers of capital assets, therefore, may act less like each other than those in the financial market. Yet even if different types of capital assets are sufficiently interchangeable, this would suggest only that they (as well as financial instruments such as tax-exempt bonds) offer the same after-tax returns as each other at any given level of risk. It still is possible, because of differences in tax treatment, that the broader asset grouping performs better after-tax than some other broad type of income-producing

${ }^{160}$ The amount of bonds that a state or local government will want to sell should be relatively finite. There are only so many uses to which the borrower is likely to want to put the funds, given nontax factors such as the limited willingness of local voters to accept higher tax burdens. 
input. For example, capital and financial assets conceivably might both be tax-favored in relation to the sale of labor for compensation (because of the realization requirement).

Given the difficulty of making broad comparisons beyond a particular type of asset grouping, the measurement of preference capitalization in the broadest sense may be close to impossible. As the following section will show, however, even without relying on broader comparisons there is reason to doubt that the value of preferences (at least for capital investments) commonly is fully capitalized.

b. Varying amounts of preference. The preceding analysis assumed that preferences have the same value for different taxpayers. This assumption is valid for tax-exempt bonds only if all prospective buyers pay tax at the same marginal rate. For many assets, however, the assumption of uniform benefit is unrealistic. Even assuming a uniform marginal rate and disregarding selective limitations, the value of a tax preference often varies among taxpayers.

Consider the tax treatment of appreciating real estate. Under a Haig-Simons approach, appreciation would be taxed annually on an accrual basis. However, the realization requirement permits deferral of the tax on appreciation, thus lowering the present value of the ultimate tax liability. ${ }^{161}$ This plainly enhances the attractiveness of real estate investments. ${ }^{162}$ The benefit may be reflected to some extent in real estate market values, due to preference capitalization. Yet the benefit from the deferral varies among taxpayers. For example, taxpayers with greater liquidity and investment diversification generally can hold property for longer periods. As a result, such taxpayers are likely to gain both longer deferral and a

161 A number of provisions enhance the value of the deferral arising from the realization requirement. For example, a taxpayer who owns appreciating real estate can exchange it for many other kinds of real estate and avoid current recognition of the gain. See $\$ 1031$ (likekind exchanges). If he needs current cash, the taxpayer can borrow nonrecourse against the appreciation without current tax consequences. Woodsam Assoc., Inc. v Commissioner, 198 F2d 357 (2d Cir 1952). If, presumably for nontax reasons, he must sell the property in a taxable transaction, he still may be able to defer the recognition of some or all of the gain by arranging an installment sale ( $\$ 453$ ) or open transaction (see Burnet $v$ Logan, 283 US 404 (1931)) in which he is compensated through interest charges for accepting deferred payment. Finally, if the taxpayer holds the property until death, its basis is stepped up to its fair market value ( $\$ 1014)$, and the appreciation permanently escapes tax.

${ }^{162}$ The realization requirement defers recognition of unrealized losses as well as gains. However, taxpayers can prevent the deferral of loss (subject to the capital loss limitation) by disposing of loss properties in taxable transactions. Given taxpayer control over the timing of realization, the requirement is on balance preferential, even without the assumption that appreciation is more frequent. 
greater chance of permanently escaping tax on the gain. If only those taxpayers who received the greatest benefit from the realization requirement held real estate investments, the tax benefit of the realization requirement would be fully capitalized. This is analogous to the full capitalization of the tax-exempt bond exclusion that one would expect under a progressive tax system when all bonds are purchased by those in the highest bracket. ${ }^{163}$

In practice, however, such an allocation of investment is unlikely with appreciated property. Expected benefit from the realization requirement varies along a continuum, instead of being the same for all taxpayers in a particular group (all those in a particular tax bracket, for instance). Moreover, pretax yields from many types of property may vary among taxpayers-as a result, for example, of variations in business skill. Thus, there is a high probability that some real estate investments will be held by those who receive less than the maximum deferral benefit.

The market cannot price discriminate on the basis of one's anticipated benefit from tax preferences. If real estate investments are held by taxpayers who receive differing degrees of benefit from the realization requirement, the amount of preference capitalization will vary greatly in different cases. For some taxpayers, the tax benefits may even be over-capitalized. Such taxpayers may pay more for the use of certain property than they would under a HaigSimons income tax, while realizing gain relatively currently. For other taxpayers, the tax benefits may be under-capitalized in varying degrees. More broadly, whenever prospective buyers receive different amounts of tax benefit from an asset, preference capitalization cannot be expected to restore horizontal equity. The implications of this point are extremely broad. All long-lived assets benefit from the realization requirement. Thus, even if many preferences pertaining to such assets are fully capitalized, overall preference capitalization may be incomplete.

\section{Summary.}

The various considerations discussed above all support the conclusion that, from a Haig-Simons perspective, we can usually expect preferences both to be unfair and to distort the allocation of resources. Instances where only one of the two problems results from a preference should be relatively rare, indeed nonexistent if one views preference capitalization as merely shifting horizontal

${ }^{163}$ See Chirelstein, Personal Income Taxation at 347-49 (cited in note 10). 
inequities.

Even if one assumes that preference capitalization increases horizontal equity, there still are only two types of exceptions to the general rule that preferences reduce both fairness and efficiency. Under the current, relatively flat tax rate structure, items such as tax-exempt bonds are only allocatively inefficient, and escape significant horizontal inequity if we ignore the benefit to issuers. By contrast, pure tax arbitrage (and related phenomena) are only unfair: since by definition they lack net economic effect, they are inefficient only insofar as they increase overhead by diverting resources to planning and record-keeping.

D. The Effect of Selective Limitations on Fairness and Efficiency, as Considered From a Haig-Simons Perspective

At last we are ready to consider whether selective limitations are second-best when considered from a Haig-Simons perspective. The question presented is whether, and under what circumstances, they may reduce the unfairness and/or inefficiency that are assumed to result from the preferences they offset.

1. Consequences of a selective limitation where the underlying preference is incompletely capitalized.

To understand the effect of a selective limitation in cases where preference capitalization is incomplete (the direct recipient of a preference retaining some after-tax benefit), it is useful to consider the effect of partially repealing the underlying preference in a manner that applies to all taxpayers uniformly. It should be clear (under Haig-Simons assumptions) that this will increase both horizontal equity and allocative efficiency. A reduction in the preference means that there is less total subsidy. This implies both a lesser increase in the quantity of tax-favored investment and a smaller after-tax windfall for buyers and sellers to divide among themselves. ${ }^{164}$

164 The view that, under Haig-Simons assumptions, reducing a preference improves horizontal equity is not disproved by arguments that, in some cases, it may lower tax revenues. Consider, for example, the argument that reducing or eliminating the capital gains preference lowers tax revenues by reducing the frequency of realization. This argument posits voluntary decisions by owners of appreciated property to pay more tax as the tax price of realization declines. Owners of appreciated property are under-taxed when they can exclude from income unrealized gain (unless they are over-taxed in other respects, perhaps due to the taxation of inflationary gains). Yet one would hardly expect them voluntarily to pay more tax (by realizing more gain) except when they believe that, in the aggregate, this makes them even better off. Generally, this is the case when the tax voluntarily paid is less 
Now consider the effect of a selective limitation that offsets the benefit of the preference and applies to some but not all buyers of the tax-favored asset. (The analysis is applicable to sellers as well.) If enough of them are not subject to the limitation, or can avoid it at low cost by rearranging their business affairs (for example, by making sure that their loans are not traceable to tax-favored expenditures), then the limitation may have little impact.

If instead the effect of the selective limitation on buyers is significant (i.e., many of them cannot avoid it at other than a high cost), their demand for the tax-favored asset should be less than in the absence of the selective limitation. It will still, however, be more than it would have been if no buyers benefited from the preference. Moreover, the prevailing market price should be closer to, though still higher than, the price that would prevail in the absence of the preference.

On its face, the situation looks somewhat similar to that resulting from uniform partial repeal of the preference. It is in fact more complicated. The next two sections will, therefore, examine in greater detail first the efficiency and then the fairness effects of the significant selective limitations.

a. Efficiency effects. A selective limitation that is not easily avoided should cause a reduction in the amount of tax-favored investment. This should produce an increase in allocative efficiency (as considered from a Haig-Simons perspective), just as when the amount of the preference is reduced uniformly.

Yet the selective limitation may not actually improve efficiency. First, there are allocative efficiency costs that conceivably may outweigh the benefit of reducing tax-favored investment. In some cases, relatively inefficient producers may be exempt from the selective limitation, while efficient producers are subject to it. If so, the former will earn higher after-tax returns, and assets will be transferred to them from the more efficient producers. In other instances, an investment with a relatively low pretax return may be tax-favored by reason of a selective limitation. For example, due to the passive and capital loss rules, investors may prefer passive income to nonpassive income, and capital gain to ordinary gain. In addition, a selective limitation may have substantial overhead effi-

than the cost of being locked into an old investment (which is a type of implicit tax). Thus, the capital gains preference cannot sensibly be viewed as reducing an inequity from which the owners previously benefited. Of course, locking in unrealized gains may have efficiency costs. This arguably provides a counter-example, founded on second-best considerations, to my general assumption that moving part-way towards Haig-Simons promotes efficiency. 
ciency costs. Compared to a direct reduction in the amount of the preference, a selective limitation may give rise to far more costly tax planning, compliance, and administration. ${ }^{165}$

There is no way of predicting in the abstract whether these allocative and overhead costs will exceed the allocative efficiency gains. Presumably, the answer depends on the characteristics both of a particular selective limitation and of the markets to which it applies. Yet at least the tradeoff may be relatively determinate, allowing us to say when a selective limitation is most likely to improve efficiency.

All else being equal, a selective limitation is most likely to improve efficiency if it is hard to avoid. When taxpayers cannot avoid incurring increased tax liability with respect to otherwise tax-favored investments, they are more likely to reduce the quantity of those investments. Of course, the "negative preference" effect of selective limitations-that is, their capacity to make certain types of investments newly tax-favored-still raises concerns. Nevertheless, the best selective limitations from an efficiency standpoint are those that undercut the supposed congressional intent regarding resource allocation that sometimes is attributed to preferences.

By the same token, selective limitations are less likely to be efficient when they are easily avoided without actually changing the quantity of tax-favored investment. To the extent that such tax planning succeeds, the provisions may have no allocative efficiency benefits. The efficiency of a selective limitation also depends on its overhead costs. While such costs plainly should be kept as low as possible, even where they are high the overhead efficiency loss can be outweighed by an allocative efficiency gain.

b. Fairness effects. A selective limitation's effect on horizontal equity can be analyzed by considering the widget example discussed previously, ${ }^{166}$ with the sellers being the ones who receive the $\$ 3$ credit. In this example, the credit induced a reduction in the equilibrium price from $\$ 10$ to an amount between $\$ 7$ and $\$ 10$. A selective limitation that denies the credit to a significant group of sellers will increase the market price, but not all the way back to $\$ 10$, given the continued availability of the preference to other

${ }^{165}$ Some complexity seems inevitable, even disregarding the actual effects of existing selective limitations. By treating some taxpayers and some forms of investment more favorably than others, selective limitations intrinsically create incentives for careful tax planning. For example, taxpayers wishing to minimize the impact of selective limitations related to leverage must spend time arranging their affairs so as to reduce the amount of interest expense that they incur or that is adversely allocated.

${ }^{188}$ See text at notes 144-45. 
sellers.

The selective limitation thus increases the windfall gain captured by sellers who are not subject to it. Due to the higher price for widgets, these sellers are paying a lower implicit tax than previously, while still receiving the full $\$ 3$ tax benefit. On the other hand, the selective limitation eliminates the windfall for sellers who are subject to it, and indeed leaves them worse off than in the absence of any tax effects. Previously, due to the $\$ 3$ credit they were receiving more than $\$ 10$ per widget after tax; now, because of the indirect denial of the credit, they are receiving less than $\$ 10$ per widget after tax. Presumably, the fairer after-tax return is the one closer to $\$ 10$, the proper baseline under a Haig-Simons approach. While the overall fairness consequences for sellers seem mixed at best, and perhaps uniformly negative, there is a clear equity gain for buyers, since they are now paying closer to the full $\$ 10$ price that would prevail in the absence of any preference.

Accordingly, selective limitations' overall effect on fairness is mixed. ${ }^{167}$ It certainly reduces the total amount of the tax subsidy, unless it fails to have a significant effect. Fewer widgets may be sold than previously, and some of the sales may be less tax-favored than they otherwise would have been. A reduction in the total subsidy would suggest a possible increase in aggregate fairness. However, an analysis of aggregate fairness cannot ignore the full range of effects that the selective limitation may have. For example, such an analysis should take account of any increased planning costs that taxpayers incur by reason of the selective limitation. These increased costs may be viewed as a kind of implicit tax.

Thus the fairness and efficiency analyses look very similar. In both instances, the principal gain (if any) results from a reduction in the quantity of tax-favored investment, and a significant loss arises from increases in overhead costs. ${ }^{188}$

\section{The special case of tax-exempt bonds.}

The above analysis assumed that the underlying preferences that are offset by selective limitations are only partially capital-

${ }^{167}$ It becomes even more mixed when we recognize that, in practice, both the value of preferences and the effect of selective limitations may vary greatly between taxpayers. There may be no objective or ascertainable way of deciding whether the tax system was more equitable before or after enactment of the selective limitation.

${ }^{188}$ The question of whether there is aggregate gain may perhaps be easier to analyze from an efficiency than from a fairness perspective. At least efficiency involves identifiable costs that theoretically are quantifiable. 
ized. The analysis is somewhat different for tax-exempt bonds, where the preference is fully capitalized. As discussed above, ${ }^{169}$ full capitalization of the preference for bonds results because, while there is unsatisfied demand for bonds at the breakeven point, there is a sharp decline in demand as soon as the bonds offer a lower after-tax return (adjusting for risk) than that available from other financial instruments.

Now consider what happens when a selective limitation applies to some but not all prospective buyers, thus reducing demand. If the reduction is relatively small, its only effect will be to reduce the amount of unsatisfied demand at the breakeven point. Since there is still some unsatisfied demand, bonds presumably will continue to be sold in the same quantity as previously and at the same (breakeven) price. In such a case, the selective limitation clearly does not increase allocative efficiency. The quantity invested in tax-exempt bonds does not change. At the same time, the selective limitation may have overhead efficiency costs, resulting in a net efficiency loss.

Moreover, there is no increase in horizontal equity. Under the standard view of preference capitalization there is no equity problem to begin with, since the preference is fully capitalized away from buyers. Even under a broader view, the selective limitation does not increase horizontal equity since bond issuers receive the same windfall as previously. Thus, the selective limitation plainly does not increase aggregate equity and efficiency.

Now assume that buyers are affected by the selective limitation in such numbers as to reduce demand below the level of supply at the breakeven point. ${ }^{170}$ Under these conditions, the selective limitation actually has substantial effects. Issuers no longer can sell all of their bonds at the break-even yield. They must compete for the available buyers by offering increased yields. Accordingly, a new equilibrium price is established at which the yield is higher but the quantity of dollars invested lower than before enactment of the selective limitation. This situation resembles the results under the prior, more progressive rate structure. The selective limitation, like graduated rates, creates differences in after-tax returns from bonds. Thus, an after-tax windfall, similar to that formerly provided to taxpayers in higher rate brackets, now must be pro-

160 See text at notes $160-63$.

170 One way in which a sufficient number of buyers might be affected is if many buyers have some indebtedness, and a stacking or "taint first" rule is used to attribute the debt to one's tax exempt bonds without regard to tracing. 
vided to taxpayers who are not subject to the selective limitation.

Under these circumstances, the conventional view of preference capitalization would suggest that horizontal equity has been reduced. Bonds now must offer a higher pretax yield than before, providing a new after-tax windfall to buyers who are not subject to the selective limitation. If one adopts the broader view that preference capitalization merely shifts inequities, however, there may be an aggregate equity gain. The increase in the pretax yield available from tax-exempt bonds provides a windfall to some buyers, but it implies a reduction in the windfall to issuers. As a result of the selective limitation, issuers now are forced to pay yields closer to the market rate that would have prevailed in the absence of the underlying tax preference.

Moreover, there will be fewer bonds providing windfalls than before, and thus less total subsidy from the preference. The selective limitation, therefore, may well increase horizontal equity. It also may increase allocative efficiency, since the over-supply of taxexempt bonds is not as great as before. There may also arise, however, significant overhead efficiency costs (also relevant to fairness as a kind of implicit tax), given the number of taxpayers who may be affected in order to eliminate unsatisfied demand at the breakeven point.

\section{The special case of pure tax arbitrage.}

A second situation that requires separate consideration is pure tax arbitrage, where taxpayers reduce their tax liability without producing any net economic change. Due to this lack of economic change, pure tax arbitrage and similar transactions reduce horizontal equity without affecting allocative efficiency. ${ }^{171}$ The analysis of selective limitations in the two prior sections is inapplicable to pure tax arbitrage. I have argued that the main potential benefit from selective limitations is a reduction in the quantity of tax-favored investment. Pure tax arbitrage, however, does not affect the actual allocation of net investment. Beyond overhead efficiency concerns, pure tax arbitrage presents only the fairness problem of permitting particular taxpayers to reduce their tax liabilities.

Accordingly, selective limitations that respond to pure tax arbitrage may not have quite as broad a range of effects. To the extent that clear and simple rules can be designed to prevent pure

${ }^{171}$ Again, the effects attributed to pure tax arbitrage are a matter of degree. See text at notes 152-58. 
tax arbitrage and yet avoid over-breadth, there is a clear gain in horizontal equity without affecting allocative efficiency. For example, if two taxpayers with sizeable stock portfolios are prevented from swapping their depreciated stocks in order to realize losses, the principal effect may be that both must pay tax on something closer to their economic incomes (assuming that they have unrealized gain from other stocks).

Some are skeptical about the feasibility of designing clear and simple selective limitations to address pure tax arbitrage. Steuerle has commented on the difficulty of identifying arbitrage generally, ${ }^{172}$ and Professor Isenbergh has noted that judge-made rules addressing pure tax arbitrage may vastly increase the complexity of the tax system, thereby reducing overhead efficiency (with fairness consequences as well for burdened taxpayers). ${ }^{173}$ One must, then, compare the equity gains to these costs.

\section{Summary.}

In sum, selective limitations have mixed effects on both fairness and efficiency. Net benefit in both areas is most likely if there is a significant reduction in the quantity of tax-favored investment. All else being equal, the more easily taxpayers can elude a selective limitations through tax planning without changing aggregate investment patterns, the less likely the limitation is to provide aggregate fairness and efficiency benefits.

For fully capitalized preferences such as tax-exempt bonds, selective limitations that affect too few taxpayers may provide no fairness or allocative efficiency benefit, while reducing overhead efficiency. Finally, in special cases such as pure tax arbitrage, selective limitations may be supported by considerations of horizontal equity that are unrelated to actual investment volume. However, any such benefits should be considered in conjunction with the overhead costs of the limitations.

\section{E. Selective Limitations Under An Assumption Favoring Preferences}

The previous analysis assumed that a tax system without preferences provides an appropriate baseline for measuring fairness

${ }^{172}$ C. Eugene Steuerle, Taxes, Loans, and Inflation: How the Nation's Wealth Becomes Misallocated 70 (Brookings, 1985).

${ }^{173}$ Joseph Isenbergh, Musings on Form and Substance in Taxation, $49 \mathrm{U}$ Chi L Rev 859, 881 (1982). 
and efficiency. It treated preferences as unfair and inefficient, because they shift personal outcomes and the allocation of investment away from this baseline. The assumption was important because it made desirable the reduction of tax-favored investment (which is a possible effect of selective limitations, depending on tax planning responses). I will now change that assumption and treat a tax system with preferences as optimally fair and efficient (either in principle or given second-best reasons for preferences). How does this affect the analysis of selective limitations?

The first point that becomes clear under this alternative assumption is that one may no longer want to reduce the quantity of tax-favored investment. Indeed, unless desirable preferences result in overkill (in other words, produce more than the desired increase in tax-favored investment or benefit to favored investors), any such reduction by selective limitations is counter-productive. Accordingly, selective limitations no longer can be viewed as involving a tradeoff between benefit and harm; they instead are entirely harmful. But even if they fail to reduce tax-favored investment, selective limitations still entail costs, such as increased tax planning and inefficient shifts among holders of tax-favored investments. Thus, under the assumption that preferences are desirable and do not result in overkill, selective limitations are unambiguously harmful.

If preferences, although desirable, do result in overkill, the analysis of selective limitations is essentially the same as under the assumption that preferences are undesirable. So long as the selective limitation does not excessively reduce the benefit to favored investors or the quantity of tax-favored investment, it will increase fairness and efficiency in some respects, albeit in exchange for certain fairness and efficiency costs.

But why should a preference that results in overkill be made subject to a selective limitation, instead of being directly reduced in value or amount? As under the assumption that preferences are undesirable, adopting selective limitations appears clearly inferior. It creates secondary fairness and efficiency costs that could be avoided by reducing the amount of preferences directly. Thus a selective limitation can be defended only as a second-best response to political (or other) constraints on more direct action. ${ }^{174}$

Thus it is always irrational, in the absence of political (or other) constraints, to introduce selective limitations to a tax sys-

${ }^{174}$ An example of a nonpolitical constraint is the administrative cost of attempting to measure income accurately. 
tem. If other avenues are available, one should not, for example, create a tax exemption for bonds along with $\S 265$, or accelerated depreciation along with nonrefundability. One should instead either repeal the preference, reduce its amount directly, or continue to allow it in full and unconditionally.

F. The Application of Selective Limitations to Tax Benefits that are Not Preferences or Otherwise Associated with the Under-Measurement of Income

Now consider the application of selective limitations to tax benefits that are not preferences or otherwise associated with the under-measurement of income-for example, where a taxpayer whose income has otherwise been measured accurately is affected by nonrefundability or the passive loss rules. Taxpayers will, of course, attempt to structure their affairs to avoid encountering such net income limitations, without regard to whether the tax benefits being denied are preferences. For example, to avoid nonrefundability companies may merge (thus increasing the pool of net income that is available to offset deductions) or avoid risky investments. Similarly, individuals subject to the passive loss rules may avoid risky passive investments in situations where they do not have significant passive income, and also will seek to convert nonpassive into passive income when they are making a risky passive investment.

Given these responses, the provisions have costs even apart from any reduction in the quantity of affected investment. Moreover, to the extent that they reduce certain investment, selective limitations operate as a negative tax preference, resulting in less such investment than the Haig-Simons definition would suggest. Thus, the effect of selective limitations on tax benefits that are not preferences, like its effect on desirable preferences, is unambiguously bad.

IV. A Second-Best Assessment of the Principal Existing Selective Limitations that Apply a Net Taxable Income Limit on Deductions

The preceding section described general guidelines for assessing the merits of selective limitations from a Haig-Simons perspective. This section begins by discussing the implications of the general guidelines for each of the principal selective limitations that applies a net taxable income limit on deductions. It then draws general conclusions from the particularized analyses. 


\section{A. Analysis of the Principal Existing Such Provisions}

1. Nondeductibility of expenses related to tax-exempt income (§ 265).

Section 265 is perhaps the easiest of all selective limitations to analyze. Given the special characteristics of the market for tax-exempt bonds (in particular, unsatisfied demand), § 265 plainly serves no purpose if it merely leads to avoidance transactions instead of reducing relevant investment. The ease with which most taxpayers can avoid $\S 265$ strongly suggests that it will not affect enough taxpayers to eliminate unsatisfied demand. Taxpayers can avoid the provision at low cost, not only by selling (or not buying) bonds whenever they suffer liquidity constraints, but also by structuring their loans carefully to avoid tracing. For example, when a taxpayer has only $\$ 500$ of cash and wants to buy both a $\$ 500$ business asset and a $\$ 500$ tax-exempt bond, he will spend his cash on the bond and use loan proceeds to buy the business asset. ${ }^{175}$

If $\S 265$ reduced demand for tax-exempt bonds to less than supply at the breakeven point, one would expect issuers to start offering increased yields as they competed to sell their bonds to scarce buyers. Just as, under pre-1986 law, they offered windfalls to buyers in high tax brackets in order to attract those in lower brackets, ${ }^{176}$ issuers now would offer windfalls to those not subject to $\S 265$ in order to attract those who are subject to it.

Given the impossibility of price discrimination, a new equilibrium price would arise at which the after-tax return (disregarding $\S 265$ ) would exceed that available from otherwise similar but taxable financial instruments. The evidence, however, suggests that this is not happening. Instead, tax-exempt bonds appear to offer about the same return as other financial instruments, adjusting for direct tax liability but not for $\S 265 .{ }^{177}$ Thus $\S 265$ probably is not improving either allocative efficiency or horizontal equity, and it presumably is increasing overhead costs. Accordingly, there is little reason for retaining it as currently constituted.

The analysis might change if tracing were replaced for all taxpayers by a stricter standard of interest allocation, such as pro rata allocation or a "taint first" rule. Under a stricter standard, demand

${ }^{175}$ A more rigorous pro rata allocation standard applies to financial institutions, which presumably are responsible for a significant portion of overall demand. Section $265(\mathrm{~b})$. This provision requires allocation to tax-exempt bonds of a percentage of overall interest expense equal to the percentage of the taxpayer's assets that are tax-exempt bonds.

${ }_{176}$ See Chirelstein, Federal Income Taxation at 349-51 (cited in notè 10).

177 See note 147. 
might decline sufficiently to increase the yield from tax-exempt bonds and reduce the quantity thereof (and the general analysis of selective limitations would apply). ${ }^{178}$ The analysis of $\S 265$ also might change if the provision were extended to other assets (such as investments that are effectively tax-exempt due to preferential cost recovery). In that case, assuming less or no unsatisfied demand for such assets, the provision would be more likely to reduce the amount of those tax-favored investments. But even here the volume effect might not be significant if taxpayers could too easily avoid an adverse allocation of interest expense.

As a general matter, if allocation issues can be resolved satisfactorily (which may be extremely unlikely), interest disallowance rules may result in lower overhead costs than most other selective limitations. Interest expense often is relatively easy to identify-at least in comparison to defining, say, a passive activity or capital asset. Even when the identification of interest expense is difficult, as where one must distinguish debt from equity or determine the rate of interest accrual on a discounted obligation, identification may be necessary for other tax reasons and thus may not be a marginal cost of anti-leverage selective limitations.

Moreover, deduction disallowance rules (whether or not applied to interest expense) are almost always less complicated than schedular rules, which require "basketing" large groups of income and deduction items. A revised and expanded $\S 265$, then, could conceivably be the best kind of selective limitation rather than the kind that is most obviously wrong. For example, one could adopt a rule flatly disallowing interest deductions to the extent that the underlying debt principal does not exceed one's basis in certain identified types of tax-favored assets. Under such a rule, if a taxpayer owned tax-exempt bonds with a basis of $\$ 10,000$, then $\$ 10,000$ of his debt liability (unless his total liability was less) would be allocated to the bonds, and interest on such debt would be nondeductible.

While such a rule clearly would involve some complexity (along with other fairness and efficiency costs) it might be both simpler than the tax law's current array of selective limitations and

${ }^{178}$ One might object to the increased yield on non-Haig-Simons equity grounds, since it would transfer a portion of the net tax benefit from bond issuers to investors who are not subject to $\S 265$. For example, one might prefer to benefit the issuing jurisdictions on vertical equity grounds, if their residents are less affluent on average than bond buyers who can avoid $\S 265$. Or, one might believe that windfalls should be spread broadly rather than narrowly, and thus prefer to benefit residents if they outnumber buyers. 
more effective in reducing the volume of tax-favored investment. Unfortunately, the rule's very effectiveness in denying the benefit of preferences to taxpayers with debt obligations probably ensures that it will not be enacted.

2. Nondeductibility of personal interest (other than qualified residence interest).

In theory, a rule disallowing personal interest deductions can be a powerful tool for reducing aggregate distortions in the income tax system. The principal distortion that such a rule can address is the exclusion of imputed rental income from durable consumer assets. In general, the income tax system reaches such income only indirectly, by denying deductions for depreciation (as well as for realized losses) of such assets. ${ }^{179}$ This leaves an aggregate tax preference when the rental value exceeds economic depreciation. The preference presumably reduces horizontal equity and allocative efficiency. It also increases both the amount of durable consumer assets in the economy and the extent to which such assets are owned by users rather than rented.

A rule disallowing personal interest deductions can be effective in reducing the above distortion because interest allocation is less of a problem here than under $\S 265$. Many taxpayers do not have sufficient liquidity to buy expensive durable assets such as homes or cars without borrowing a portion of the purchase price and giving the lender a security interest in the purchased asset. Even though such a rule can readily be defeated at the margin (by taxpayers who reduce their borrowing or make sure that they can trace their loans to business assets), it should reduce the aggregate subsidy. ${ }^{180}$

The case for interest disallowance is weaker when the underlying personal expenditure does not involve the acquisition of a durable asset. ${ }^{181}$ For example, disallowing deductions from a vacation

179 See Epstein, 23 Stan L Rev at 457-60 (cited in note 24).

180 To some extent, the disallowance of personal interest expenses may reduce vertical equity (depending on how it is defined). Wealthy taxpayers are more able than others to avoid debt-financing. Therefore, they are less likely than middle-class taxpayers to be affected by the provision. Yet this effect arguably is countered by the fact that the underlying exclusion for imputed rental income disfavors poor taxpayers-those who cannot afford to buy durable consumer assets even with debt.

${ }^{181}$ Moreover, the case for interest disallowance is weak when the underlying expenditure arguably serves business as well as personal purposes. An example is a loan to pay for education that increases the taxpayer's expected lifetime earnings. Such a loan is treated as a personal expenditure for tax purposes despite the business component. 
loan that gives rise to interest payments in years after the vacation presumably would reduce the amount spent on vacations. It is not clear, however, that this would be a more allocatively neutral result, since allowing the interest deduction may not be preferential to begin with.

Calvin Johnson argues that the impatience avoided by borrowing to pay for an earlier vacation is a form of imputed income that the tax system properly reaches indirectly by denying the interest deduction. $\mathrm{He}$ analogizes the interest expense incurred to finance an earlier vacation to the added (and nondeductible) principal cost of a more expensive or "nicer" vacation. ${ }^{182}$ Restated more broadly, Johnson's argument suggests that consumption in one year has an income value in subsequent years, whether derived from pleasant memories or from the avoidance of unpleasant feelings of deprivation. In a sense, he suggests that consumption in any one year, whether or not debt-financed, should be viewed as yielding interest-type income in subsequent years.

This argument has some force. Consumption or deprivation in one year obviously can have carryover effects on a taxpayer's psychic well-being in later years. Taxpayers recognize this, which is one reason why they do not always defer consumption, even though (if one disregards the risk of death) deferral permits them to consume more, in dollar terms, whenever the real interest rate is positive. The failure to account for the continuing value of past consumption largely explains the income tax's apparent bias for consumption over saving. ${ }^{183}$

Yet consumption does not always have a carryover value, and may not have the same value in all cases. Moreover, there is no market proxy that can be used to measure carryover value, except to the extent that interest rates influence taxpayer choices about the timing of consumption. Carryover value is a classic example of the highly refined and subjective psychic income values that the Haig-Simons definition disregards for administrative reasons. ${ }^{184}$ Accordingly, there is no clearly correct answer to the question of how to treat personal interest expenses that are not associated with the purchase of durable assets, short of going beyond HaigSimons to allow deductions for all costs (including personal inter-

182 Johnson, $6 \mathrm{Va}$ Tax Rev at 160-61 (cited in note 18).

${ }_{183}$ See Andrews, 87 Harv L Rev at 1115 (cited in note 126).

${ }^{184}$ Similarly, the definition disregards consumer surplus, and thus does not reach the added value of a "nicer" vacation, except to the extent that it is more expensive than a lesser one. 
est) and taxing all psychic values as income. And it is not clear whether allowing or disallowing the interest deduction for personal expenditures, such as vacations, that do not give rise to tangible assets would be more neutral with regard to resource allocation. Again, this depends on the extent to which one believes that such expenditures give rise to a continuing income stream in the form of pleasant memories and reduced impatience.

To the extent that one is skeptical about the carryover value of consumption, one could question whether the existing personal interest rules increase allocative efficiency (or horizontal equity) by disallowing deductions for all consumer debt, regardless of the retention of a durable asset. However, an even more serious objection to the current rules concerns the exception for qualified residence interest (generally, interest on up to $\$ 1.1$ million of debt that is secured by one's home(s)). ${ }^{185}$

Given this exception, the personal interest rules clearly fail to address the tax preference for home ownership. Yet homes are easily the most important type of personal asset that is under-taxed because of imputed rental income. They not only have a high rental value, but they often do not depreciate significantly; thus, they may be tax-favored by virtually the entire amount of the exclusion. ${ }^{186}$

Moreover, the combination of general nondeductibility for personal interest with deductibility for qualified residence interest favors home ownership even more potently than would the latter rule in isolation. A homeowner can deduct the interest on a loan used to finance personal expenditures if and only if the loan is in fact secured by his home, because the loan gives rise to qualified residence interest without regard to the purpose or to use of the borrowed funds.187 The increased marketing of "home equity loans" by banks and other lenders in the aftermath of the 1986 Act is clear evidence of the added benefit to homeowners. ${ }^{188}$

The personal interest rules, then, have mixed effects on hori-

${ }^{183}$ Section 163(h)(3).

${ }^{188}$ A personal asset such as a car may depreciate somewhat more in relation to the amount of excluded rental income.

${ }^{187}$ Of course, home equity loans are subject to a $\$ 100,000$ ceiling on debt principal. Section $163(h)(3)(C)$. However, the amount available can effectively be increased by retaining a high unpaid balance on one's acquisition indebtedness.

188 Perhaps the best thing about the qualified residence interest rules is the possibility that they will change. The $\$ 1.1$ million ceiling was established by the Revenue Act of $1987, \S$ 10102(a)(3) (cited in note 22). If budgetary pressures continue to be serious (and begin to be taken more seriously), the ceiling might be lowered by a sufficient amount to reduce the aggregate tax bias in favor of owner-occupied housing. 
zontal equity and allocative efficiency. For convenience, consider allocative efficiency: personal interest rules may improve (if only minutely) resource allocation with regard to durable consumer assets other than homes. The qualified residence interest exception, however, greatly weakens this effect. And the rules clearly worsen resource allocation with regard to homes. Their effect on consumer expenditures for items (such as vacations) that do not give rise to durable assets cannot be assessed without first determining the proper baseline for measuring neutrality. This effect, however, is arguably positive since consumption presumably has some aggregate carryover value that the system ignores.

\section{The investment interest limitation.}

The investment interest limitation is one of several selective limitations that are not highly asset-specific. The rule generally prevents taxpayers from reducing taxable income by combining deductible borrowing with the exclusion of unrealized gain from the appreciation of investment assets such as stocks, loans, and raw land. ${ }^{189}$

The rule's principal effect may be to offset the benefit of the realization requirement for financial assets that are made available by one taxpayer for another taxpayer's use in a business. For example, by reducing the tax benefit of owning appreciated corporate stock, the provision may reduce the amount of stock that is issued and outstanding. But the provision may not influence the ultimate use of financial assets. If stock ownership is less tax-favored as a result of the rule, for instance, taxpayers may simply change the form in which they do business rather than the actual businesses that they conduct. They may own more businesses directly, rather than in corporate form, and make more loans to businesses instead of purchasing equity interests. ${ }^{190}$ Thus, perhaps the principal justification (if any) for the investment interest limitation relates not to allocative efficiency, but to horizontal equity. In particular, it may help prevent pure tax arbitrage (interpreted broadly to include all transfers that lack net economic effect). ${ }^{191}$ In some circumstances,

${ }^{188}$ See $\S 163(d)$.

190 Under the investment interest limitation, dividends would increase the amount of interest deductions that one could claim. Taxpayers, then, might be less averse to receiving dividends since they would not increase taxable income.

191 An additional justification for the investment interest limitation may be that it offsets, if only slightly, the net tax benefit accruing to investment assets as a result of $\$ 1014$ (the step-up in the basis of property at death). On the other hand, the limitation may be criticized for helping to preserve the dual taxation of corporate income (once at the corpo- 
the provision may prevent taxpayers from, in effect, lending money to themselves in order to generate deductible interest expense and gain that is not currently realized. ${ }^{182}$

\section{Capital loss limitation.}

The capital loss limitation, like the investment interest limitation, is not highly asset-specific. Capital asset status is determined at the taxpayer level. It turns on issues such as whether the asset is used in a business, rather than the nature of the business in which the asset is used. ${ }^{193}$

Thus, the principal justification (if any) for the rule probably also involves horizontal equity and the prevention of pure tax arbitrage (in its broad sense). Consider again the planning opportunities that would be available in the absence of the capital loss limitation to two wealthy taxpayers with sizeable portfolios of publicly traded stock. Such taxpayers could agree to sell each other all of their depreciated stocks for fair market value at the end of each taxable year. They would generate substantial tax losses without suffering any economic losses, unless the portfolios as a whole depreciated. ${ }^{194}$ By impeding such transactions, the capital loss limitation affects a more significant planning opportunity than the investment interest limitation. One can, of course, still question whether the capital loss limitation sufficiently increases horizontal equity to justify its various costs, including not only substantial overhead costs, but also horizontal inequity when affected taxpayers have no unrealized gains. ${ }^{195}$

rate and once at the shareholder levels).

${ }^{192}$ Absent the investment interest limitation, one could realize deductible interest expense along with income that is not currently realized. This could be achieved by borrowing money from one's wholly owned $\mathrm{C}$ corporation (thus requiring one to pay interest to the corporation), and having the corporation pay no current dividends on its interest income from the loan. Yet one would still face the problem of avoiding taxation of the interest income at the corporate level, particularly now that the tax rate generally is higher for corporations than for individuals.

${ }^{193}$ See, for example, $\S 1221$.

194 Again, one could view this tax planning opportunity as reducing the distortion inherent in taxing corporate income twice. On the other hand, as applied to physical assets such as land and buildings, the capital loss limitation has an additional fairness and efficiency benefit: it reduces the tax advantage that selective reallocation opportunities afford to long-lived assets.

${ }^{193}$ One problem with the capital loss limitation is that the capital asset category was designed by Congress and the courts principally to accommodate the prior capital gains preference, rather than to address the selective realization of losses. Thus, assuming that the preference is not restored, the capital asset category could be revised to focus more narrowly on assets (such as stocks) that are highly subject to individual fluctuation and that com- 


\section{Passive loss rules.}

The passive loss rules, like the investment interest and capital loss limitations, do not focus on any particular tax preference or type of asset. Instead, they restrict the deduction of net losses from activities whose "passivity" is determined at the taxpayer level, generally based on material participation.

The passive loss rules have a far greater potential than the prior two rules to affect allocative efficiency. The material participation standard that is used to identify most passive activities is, on its face, both arbitrary and manipulable. In practice, however, this standard may have some aggregate tendency to focus the effect of the passive loss rules on investments that are relatively taxmotivated, and that presumably have below average anticipated pretax profitability. ${ }^{196}$

Moreover, the passive loss rules may improve allocative efficiency to the extent that they reduce investment in assets that typically are used in rental activities (such as real estate and equipment). Rental activities commonly produce tax losses even when apparently economically profitable. ${ }^{197}$ This can make them good investments on an after-tax basis even when other investments are significantly more profitable before tax. Thus, one would expect over-investment in the assets typically used in rental activities absent the passive loss rules, which implies a possible reduction of such over-investment as a result of the rules. ${ }^{198}$

Finally, because the passive loss rules limit losses from passive activities without disfavoring gains ${ }^{199}$ a shift may occur towards investments that are more profitable before tax. One hears anecdotally about recent shifts in real estate syndications from "loss" deals to "income" deals. Many investors now seek "passive income generators," or "PIGs" (although the Treasury seeks to

monly are held in large portfolios.

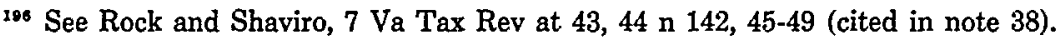

${ }^{197}$ See id at $43 \mathrm{n} 142$. Tax losses for profitable rentals may have resulted in part from the availability of more favorable cost recovery (including the investment tax credit) under pre-1986 law. However, cost recovery still may be preferential on balance, especially for long-lived assets such as real estate, due in part to the exclusion of unrealized appreciation.

${ }^{198}$ On the other hand, since the passive loss rules generally exempt working interests in oil and gas, they may inefficiently increase oil and gas investment. Section 469(c)(3).

199 Of course, the disparate treatment of losses and gains distorts taxpayer incentives and discourages risk-taking-especially to the extent that economic losses, not just tax losses, are subject to disallowance. The rule allowing the deduction of losses from a passive activity when the taxpayer disposes of his entire interest therein reduces, but does not eliminate, this distortion. 
recharacterize many such arrangements as nonpassive). ${ }^{200}$ While the shift to PIGs may be allocatively inefficient if it displaces investments that produce nonpassive income, it is likely to be efficient if it displaces investments designed to produce passive losses.

What makes the passive loss rules potentially significant is the difficulty many taxpayers have converting nonpassive income into passive income, or passive loss into nonpassive loss. Consider compensation for services. For many taxpayers, such as professionals and salaried employees, it is not feasible to convert significant amounts of compensation income into passive income. Moreover, it is often not feasible or desirable for most people to spend sufficient time on an additional business investment to qualify as a material participant. Some taxpayers, however, such as entrepreneurs who own and operate a variety of businesses, may have considerably less difficulty creating passive income and nonpassive losses; but the passive loss rules probably reduce substantially the pool of investment dollars that are available for investments designed to produce tax losses.

On balance then, the passive loss rules may bring about significant investment changes, and it is possible that in the aggregate these changes will increase allocative efficiency. Yet the overhead costs of the passive loss rules are extremely high. The rules are nightmarishly complicated, probably beyond the comprehension of most taxpayers who need to know about them, and call for extensive tax planning and record-keeping. ${ }^{201}$ Moreover, the rules penalize risky passive investments even if the investments do not benefit from tax preferences.

\section{Nonrefundability.}

Nonrefundability, like the passive loss rules, discourages investments that are expected to produce tax losses. While this clearly would be undesirable in a system that measured income accurately (since it would penalize risk-taking by undiversified investors), its allocative effects are more uncertain in a preferential tax

${ }^{200}$ See, for example, Daniel N. Shaviro, No to "NOPAs:" Non-shelterable Passive Activities Under the Passive Loss Regulations, 4 Tax Mgmt Real Est J 135, 136 (1988).

${ }^{201}$ See Daniel N. Shaviro, Compliance and Enforcement Under the Passive Loss Regulations, 4 Tax Mgmt Real Est J 107 (1988). The overhead costs, even if outweighed by allocative efficiency gains (which is far from clear), probably could be reduced in various respects-for example, by replacing overall "basketing" with a ceiling on the losses from business activities (whether passive or not) that can be deducted against salary or portfolio income. Id at 113. Admittedly, this might reduce allocative efficiency if it caused the rules to focus less on tax-favored investments. 
system. Nonrefundability may cause some taxpayers to seek greater pretax profitability and less tax benefit from their investments.

However, nonrefundability is less focused in this regard than the passive loss rules. It applies to the aggregate of all items on the tax return, not just to a subgroup of items that may reflect a lower than average degree of expected pretax profitability. At the same time, nonrefundability should result in lower overhead costs than the passive loss rules. Administration and compliance are relatively uncomplicated, although increased by provisions that restrict the transferability of tax attributes such as net operating losses and excess credits. ${ }^{202}$

The application of nonrefundability to true economic losses is particularly unjustifiable. At best an accidental byproduct of the attempt to reduce the aggregate effects of undesirable tax preferences, nonrefundability arguably is not even necessary to the pursuit of that goal. Consider net operating losses computed with respect to alternative minimum taxable income. If the alternative minimum tax comes close to measuring economic income accurately, one could argue that such net operating losses should be refundable (at the appropriate marginal rate), ${ }^{203}$ since presumably they are not attributable to preferences. ${ }^{204}$

I noted earlier the intuition underlying nonrefundability that is wholly separate from concern about preferences: the view that the income tax system properly involves only payments to, not from, the government. ${ }^{205}$ The analysis in this article should make clear the costs entailed in adhering to this intuition. Treating tax liability as only positive and never negative has two harmful consequences: (1) in some cases true economic losses will have no tax

${ }^{202}$ See $\S \S 381-383$.

${ }^{203}$ Since the alternative minimum tax base would be used for this purpose solely to determine the amount of the true economic loss, the amount refundable arguably should be computed using the regular tax rates.

204 A refund provision based on alternative minimum taxable income would add signifcant complexity to the interaction of the regular tax and the alternative minimum tax. For example, timing differences make it possible that for a given year one could have a larger net operating loss under the regular tax. A possible solution would be to make the alternative minimum tax net operating loss refundable only to the extent that it did not exceed the regular tax net operating loss for the taxable year. One could similarly propose that the amount of one's passive loss, as computed for purposes of the alternative minimum tax, be deductible against nonpassive income under the regular tax. However, the passive loss rules may largely apply to investments that are likely to have economic income in excess even of alternative minimum taxable income. See Rock and Shaviro, $7 \mathrm{Va}$ Tax Rev at 36-39 (cited in note 38 ).

${ }^{205}$ See text at note 43 . 
effect, and (2) taxpayers will engage in a variety of costly avoidance transactions that serve no purpose other than preserving the effective allowability of excess deductions.

\section{Pretax accounting profit requirement.}

If the economic outcome of an investment could always be predicted accurately in advance, and if taxpayers were motivated solely by after-tax profitability, a requirement of pretax accounting profitability conceivably might improve allocative efficiency. Investments that were unprofitable before tax, and that were made solely because of tax preferences, presumably would be replaced by more productive investments. Moreover, if foregone income from alternative (but fully taxed) investment opportunities were treated as equivalent to interest actually paid, theoretically the requirement would force taxpayers to make the most profitable investment available in all cases.

Obviously, however, the assumption that pretax profitability can accurately be predicted is often wildly unrealistic. Moreover, taxpayers do not always seek to maximize after-tax profitability. They also invest their capital and labor in ways that are relatively unprofitable for reasons of personal taste. And there seems no reason to penalize taxpayers for making unprofitable investments that reflect personal predilections (unless one is moving beyond even Haig-Simons income to a comprehensive psychic income base).

Thus, the pretax accounting profit requirement may best be applied, as it currently is, as a limited judicial device for addressing obvious examples of pure tax arbitrage. ${ }^{206}$ The fairness benefit of preventing certain facially reciprocal and economically insignificant transactions (like the one in Knetsch) from reducing tax liability should be weighed against the overhead costs of applying a relatively imprecise and unpredictable judicial doctrine. ${ }^{207}$

B. General Conclusions About Selective Limitations that Apply Net Taxable Income Limits

The various selective limitations that apply net taxable income limits have similar but not identical strengths and weaknesses. Some appear potentially more effective than others. What general conclusions can be drawn from the relative success of the different selective limitations discussed in this article? Are some 
approaches intrinsically more promising than others? For example, are provisions that deny certain deductions outright more or less promising than schedular provisions? Or is tracing a good method of identifying the interest expenses that are subject to a particular rule?

Unfortunately, no conclusions can be drawn on that level of generality. For example, compare the ineffectiveness of one deduction disallowance rule, $\S 265$, with the likely effectiveness of a hypothetical rule disallowing home mortgage interest deductions. The latter provision would probably be quite effective even under a tracing rule, due to many taxpayers' inability to buy an asset as expensive as a home without incurring traceable debt. ${ }^{208}$

The distinction between $\S 265$ and a rule disallowing home mortgage interest deductions helps to isolate the critical test for determining whether a selective limitation is potentially desirable: Will taxpayers who otherwise would provide a significant portion of the relevant investment dollars find the provision difficult to avoid? A deduction disallowance provision meets this test if many taxpayers cannot avoid incurring the disallowed deductions-this is the case with home mortgage interest, and might be true for interest disallowance provisions generally if interest expense were allocated first to tax-favored uses. A schedular provision meets this test if, as may be the case under the passive loss rules, many taxpayers have difficulty both in keeping tax-favored investment out of the disfavored "basket" and in shifting positive taxable income (such as salary) into the basket.

A showing of effectiveness in reducing the preferences available to taxpayers from tax-favored investment does not, of course, prove that a selective limitation is desirable. It shows only the possibility of benefit, and leaves unanswered the question of cost. If a provision is not potentially effective, however, there is little reason to consider it further.

\section{Conclusion}

This article has sought to rethink the tax policy issues raised by selective limitations. It attempts to move the debate away from unavailable first-best alternatives and the question whether, in the abstract, two wrongs make a right. Instead, it argues that a meaningful assessment of selective limitations requires looking broadly at a complex range of fairness and efficiency effects. The principal

20 See text at notes $179-87$. 
fairness and efficiency gain that could result from selective limitations is a reduction in the quantity of tax-favored investment. Absent this effect, or when the investment is one that should not be reduced in quantity, selective limitations are unambiguously undesirable. Moreover, even when selective limitations reduce undesirable tax-favored investment they have significant fairness and effciency costs. The balance between benefit and cost must ultimately be evaluated empirically. 